\author{
Karol ZIELIŃSKI \\ Uniwersytet Wrocławski \\ (iD) https://orcid.org/0000-0001-9518-935X
}

\title{
MOTYW WINY HELENY W TRADYCJI EPICKIEJ I W DYSKURSIE ILIADY
}

\author{
THE MOTIF OF HELEN'S GUILT IN EPIC TRADITION \\ AND IN THE DISCOURSE OF THE ILIAD
}

The paper takes up the issue of Helen's guilt for the outbreak of the Trojan war present in the Iliad and in the oral epic tradition. It puts forward a thesis that in order to blame others or to free themselves from blame epic heroes employ the typical in oral culture technique of conducting disputes. Like other characters in the Iliad, Helen, is also under constant social pressure which seeks to find her guilty and, in effect, to activate a mechanism of making a scapegoat of her. To defend herself, she risks self-accusations in order to make it impossible for other people to bring a charge against her. Helen cares about her good opinion in the Trojan society and particularly in the circle of women.

Keywords: the Trojan Helen, the Iliad, Homer, oral culture, a scapegoat

Słowa kluczowe: Helena Trojańska, Iliada, Homer, kultura oralna, kozioł ofiarny

\section{Wstęp}

Rola Heleny w Iliadzie obserwowana jest w dużej mierze pod kątem jej winy za doprowadzenie do wojny trojańskiej. Zarówno tradycja mityczna, jak i sama Iliada dostarczają w tej kwestii sprzecznych informacji: a to jest obwiniana za wywołanie wojny, a to od tej odpowiedzialności uwalniana.

W odniesieniu do tego zagadnienia oceny badaczy zależą od przyjmowanego przez nich stanowiska co do natury poetyki dzieł homeryckich. Jeżeli nawet powszechnie nie ulega wątpliwości, że Iliada wywodzi się z tradycji oralnej, to już na pytanie, w jakim stopniu jest to produkt tej kultury, odpowiedzi 
są różne. W interesującym nas zakresie wystarczy uwzględnić, że badacze, którzy są skłonni uznawać Iliadę za dzieło w pełni oralne, akcentują tradycyjność dyskursu, gdzie poszczególne rozwiązania manifestują zakodowane w tradycji znaczenia ${ }^{1}$. Jeszcze częściej pojawiają się jednak głosy akcentujące indywidualność stylu Homera ${ }^{2}$, za czym zazwyczaj stoi przekonanie o niepełnej oralności tego dzieła. Obydwa stanowiska mają swoje słabe strony, z których kluczową, w moim rozumieniu, jest kwestia oceny charakteru kunsztu twórcy oralnego. Poszczególne utwory stanowią zawsze realizację tradycji, ale nawet jeżeli tradycja wykazuje olbrzymią stabilność na polu przenoszonych znaczeń, nie oznacza to, że znaczenia nie podlegają reinterpretacji. Kluczem do zrozumienia tego zjawiska jest obserwacja, że zmiana pojawiająca się w wykonaniu oralnym nie sprowadza się do błędów pamięci, lecz stanowić może świadomie wprowadzaną przez wykonawcę modyfikację funkcjonujących w tradycji rozwiązań, a w konsekwencji także znaczeń ${ }^{3}$. Wprowadzane zmiany w żaden sposób jednak nie przypominają innowacji stosowanych w literackim stylu indywidualnym, czyli nie-tradycyjnym (stosownie do określenia Milmana Parry'ego ${ }^{4}$ ), nowe rozwiązania wprowadzane są w drodze rekonfiguracji elementów tradycyjnych.

Inną, istotną w prezentowanej poniżej interpretacji, rolę odgrywa sposób odczytywania wypowiedzi bohaterów. W badaniach nad Homerem dominuje przekonanie, że postaci epiki uzewnętrzniają swoje uczucia i przekonania w wypowiedziach ${ }^{5}$. Nie docenia się tym samym możliwości skrywania przez nie swoich intencji. Ich wypowiedzi oparte są na potrzebie zaznaczania własnej pozycji w rywalizacji z innymi i przyjmują zazwyczaj formę sporu ${ }^{6}$, którego eskalacja może być jednak powściągana przy użyciu różnych technik mediacji i perswazji. Agresja okazywana i powściągana przez bohaterów homeryckich wynika z realności zagrożenia, jaką niosą ze sobą ich wypowiedzi. Wypowiedzi bohaterów mają charakter publiczny (warunkują więc potwierdzenie pozycji jednostki w grupie) i każde podważenie ich zdania może oznaczać narażenie ich na dysrespekt, który

${ }^{1}$ Głównymi przedstawicielami tego nurtu są z pewnością Gregory Nagy (np. 1996; 2010), Leonard Muellner (1996) czy John Miles Foley (1991), który opracował koncepcję tradycyjnej referencyjności, stosownie do której każdy produkt i element tradycji oralnej realizowany w performensie jest metonimicznie osadzony w poprzedzających go w danej tradycji innych performensach. W odniesieniu do tematu winy Heleny spośród przywoływanych poniżej badaczy stanowisko to reprezentują Graver 1995 i Ebbot 1999.

${ }^{2}$ Pośród przywoływanych poniżej badaczy stanowisko to reprezentuje Roisman 2006.

${ }^{3}$ Goody 2012; Zieliński 2021.

${ }^{4}$ Parry 1987: 266-269, 314-324.

${ }^{5}$ Np. Griffin 2004, który wskazuje na brak charakterystyk i objaśnień zachowania postaci wprowadzanych przez narratora.

${ }^{6}$ Najistotniejszą rolę odgrywa w tym względzie odczytanie charakteru dyskursu homeryckiego dokonane przez Richarda Martina (1989). Rywalizację dyskursów słownych w greckiej kulturze oralnej omawia również Collins 2004, który rozpoznaje metodę kompetytywnego prześcigania się w słowach (capping) uczestników dyskursu. 
prowadzi do pozbawienia jednostki szacunku grupy, a nawet do dobrowolnej lub przymusowej separacji ${ }^{7}$. Każda porażka słowna oznaczała więc obniżkę prestiżu jednostki, ale mogła też nieść ze sobą daleko poważniejsze konsekwencje, z eliminacją takiej jednostki włącznie ${ }^{8}$.

Wina w społeczności homeryckiej nie jest też postrzegana tak jak współcześnie. Ludzie są odpowiedzialni nie tyle za swoje czyny, ile za swoje nieszczęścia i w każdym nieszczęściu rozpoznawana jest wina moralna. Wina nie jest uświadamiana w momencie popełniania czynu - zostaje dopiero rozpoznawana w sytuacji, gdy ludzi spotyka coś złego lub niepomyślnego. W ten sposób rozpoznawane jest nie tylko nieszczęście indywidualne, ale i zbiorowe, a wówczas postępek jednostki irracjonalnie uznany za przyczynę klęski dotykającej społeczność może ściągnąc na tę jednostkę agresywne działanie grupy, która żyje w przeświadczeniu, że postępek ten naraża ich na gniew bóstwa strzegącego zasad, które dany postępek naruszył. Jednostce wytypowanej jako źródło zła grozi separacja, a w sytuacjach skrajnych także pozbawienie jej życia.

Ludzie kultury oralnej stosunkowo łatwo skłonni są zrzucać winę na bogów, według tej samej zasady, którą Evans-Pritchard dostrzegł w postępowaniu jednostek z plemienia Azande, które chętnie zrzucały winę za dotykające ich nieszczęście na czary, mimo że inni określali ich nierozważne zachowanie jako głupotę?. Ten

7 Stosownie do koncepcji Erica Doddsa (Dodds 1951: 1718), deklarującej podział kultury ze względu na sposób formułowania winy na shame i guilt culture, społeczeństwo homeryckie przynależy do kultury wstydu obliczonej na uwzględnianie przez jednostkę jedynie opinii innych. $\mathrm{Na}$ stanowisko to spadła jednak krytyka podważająca założenie, że człowiek kultury wstydu był pozbawiony poczucia winy (patrz Dover 1975: 236-243; Hooker 1987; Lloyd-Johnes 1990; Cairns 1993 oraz 2011: 790-791; Compton 2006: 37-40). Niemniej Ong (2011: 82-84), charakteryzując człowieka kultury oralnej, wskazuje na jego nieumiejętność charakteryzowania samego siebie i uzależnienie wizji samego siebie od opinii innych. Spory w kulturach oralnych (Collins 2004: 231-235) mają charakter regulatora zachowań społecznych i wynikają z potrzeby uwzględniania szacunku w relacji do hierarchicznej pozycji jednostki w społeczności.

${ }^{8}$ Zjawisko kozła ofiarnego często błędnie redukowane jest do sytuacji rytualnej, w której wykluczeniu (ze skutkiem śmiertelnym włącznie) podlegają jedynie osoby z marginesu społeczeństwa. W istocie pełnią one jedynie rolę substytutów, których pozbycie się łączy się z przyjmowaniem swoistego rachunku społecznego i ekonomicznego (Green 2002: 28-29). Mechanizm kozła ofiarnego dotknąć jednak może każdą osobę, która w ten czy inny sposób uznana zostanie za siedlisko winy moralnej. Oczywiście, z jednej strony, pewne cechy wskazujące na odmienność i odstępstwo od normalności będą zawsze ułatwiały występowanie z takimi oskarżeniami wobec tak postrzeganych osób. Z drugiej strony jednak, zarzuty stawiane jednostce deprecjonują jej wartość i przedstawiają ją jako osobę nie zasługującą na szacunek, a wręcz przeciwnie na pogardę i odrzucenie, jako jednostkę występną i stanowiącą zagrożenie dla społeczności. Dlatego dla każdej jednostki istotne jest zachowywanie dobrej opinii o sobie, pozwalającej na utożsamianie się z nią grupy. Dbanie o ludzki szacunek oznacza w praktyce utrzymywanie przez daną jednostkę przekonania grupy, że nie wykracza ona poza uznawaną przez grupę normalność.

${ }^{9}$ Evans-Pritchard (1976: 78). Podobnie Turner (1970: 300): „It might be argued that words such as 'misfortune,' 'accident,' 'bad luck,' 'mischance' are 'erroneous translations of malwa and its synonyms, for there is indeed no concept of 'accident' among the Ndembu, who seek to find a cause 
sam badacz relacjonując poczucie winy u Nuerów dostrzega, że same zakazy nie są wcale traktowane kategorycznie i ludzie często ryzykują postępowanie, które może ale nie musi być niewłaściwe ${ }^{10}$. W wypadku niepowodzenia żałują swojego postępowania, ale też widzą je w perspektywie błędu, którego nie byli świadomi. Analogicznie William Wyatt zinterpretował znaczenie homeryckiego pojęcia atē, na które powołuje się Agamemnon oczyszczając się z winy, jako żałowanie po fakcie tego, co się zrobiło. Wyatt zauważa przy tym, że zachowanie takie jest elementem układu społecznego, w którym od jednostek oczekuje się pewnych zachowań pozwalających naprawić i wynagrodzić wyrządzoną krzywdę, dzięki czemu możliwe jest przywrócenie porządku społecznego (Wyatt 1982). W efekcie, publiczne przypisanie komuś winy, z jednej strony, może być nawet śmiertelnie niebezpieczne dla jednostki rozpoznanej jako zagrożenie dla przetrwania grupy, $\mathrm{z}$ drugiej, podlega negocjacjom. Irracjonalność bowiem powiązania nieszczęścia $\mathrm{z}$ nieodpowiednim zachowaniem daje duże pole manewru dla jednostek, które mogą starać się na przykład przerzucić winę na kogoś innego: czy to człowieka (zwłaszcza tego, który ich oskarża), czy to siły „,nadnaturalne”, takie jak bóstwa czy czary (choć obie te siły będą w tych kulturach traktowane jako całkowicie naturalne).

Daje to okazję do wykazywania się umiejętnościami odsuwania od siebie oskarżeń i utrzymywania swojej pozycji w grupie jako niezagrożonej. Bohaterowie Iliady, rozmawiając ze sobą, niemal cały czas balansują nad przepaścią. Homerycki opis zachowania bohaterów epiki stanowi więc rodzaj opisu kultury „od wewnątrz” (stosownie do postulatu badawczego Victora Turnera), w którym nie stosuje się perspektywy obiektywnego dystansu, jak choćby w historiografii lub w powieści, lecz uwaga skoncentrowana jest na intencjach wypowiadających się postaci i ich zapasach słownych, których wynik jest zawsze niepewny. Każda wypowiedź może zarówno podnieść rangę jednostki, dzięki akceptacji grupy dla jego zdania, lub pogrążyć ją, nawet niezależnie od pozycji zachowywanej w hierarchii. Do zrozumienia zatem postępowania i wypowiedzi bohaterów Iliady niezbędne jest postrzeganie ich w perspektywie funkcjonowania społeczeństwa tradycyjnego kultury oralnej, o którym wyobrażenie dostarczają etnologiczne opisy współczesnych kultur oralnych. Jednostka czuje się zawsze częścią grupy i na akceptacji grupy przede wszystkim jej zależy. Nie znaczy to, że brak jej poczucia indywidualności (jak czasami twierdzono), lecz że dążenie do zdobycia akceptacji społeczności podminowane jest zagrożeniem separacji, a sukces jednostki mierzony jest zdobyciem poparcia grupy dla swojego zdania, często w kontrze do zdania innej jednostki. O dużym niezrozumieniu wobec tego możemy mówić, gdy

for every calamity; far from being 'prelogical,' they are obsessively logical, though on the basis of mystical premises, as Evans-Pritchard (1976: 18-32) showed us in his classical study of Azande systems of belief. The Ndembu, like the Azande, consider that calamities and adversities of all kinds are caused by mystical forces generated or evoked and directed by conscious agents". Patrz również Evans-Pritchard 1956: 193-194.

${ }^{10}$ Evans-Pritchard 1956: 16-22; Douglas 2007: 131-133. 
w badaniach filologicznych nad poematami homeryckimi ocenia się daną postać pod względem charakterologicznym przyjmując za dobrą monetę to, co postać sama o sobie mówi lub co mówią o niej inni (w istotnym dla nas kontekście niemal jak aksjomaty wypowiada się na przykład sądy o oczywistości winy Parysa lub jego zniewieściałości, z czym miałaby kontrastować postawa Heleny). Wynika to z błędnego odczytania świata homeryckiego jako konfliktu egotycznych jednostek. Ocena takich postaci musi być bezwzględnie powiązana $\mathrm{z}$ dostrzeganiem stopnia partycypacji jednostki w grupie, rozpoznaniem presji grupy na jednostkę i roli odgrywanej przez jednostkę w grupie. Wszystkie te wartości nie mają charakteru statycznego, tzn. nie ograniczają się do pełnienia w grupie pewnej stałej funkcji przez jednostkę (np. ktoś jest królem, żoną króla itp.), lecz dynamiczny, tzn. kontekst sytuacyjny zmusza ją do obrony swojej pozycji lub pozwala jej na próbę podniesienia swojego prestiżu dzięki uzyskiwaniu wsparcia grupy.

\section{Wina i niewinność Heleny - stań badań}

Kenneth Mayer jest zdania, że postać Heleny jest elementem koncepcji mitycznej, w której bogowie postanawiają pozbyć się kłopotu nadmiernego rozrostu populacji ludzkiej przez zesłanie im katastrofy (Mayer 1996). Mayer słusznie zauważa, że mit ten pełni funkcję wyjaśnienia przyczyny obecności nieszczęścia i śmierci w życiu ludzi. Helena jest określona jako pēma 'nieszczęście, klęska' przez Hektora (III 50-51), podobnie jak w tradycji hezjodejskiej Nemezis, apoteoza wyrównującej rachunki zemsty, (Theog. 223) oraz Pandora (Theog. 592, $O p .82$ ). W jednej z wersji tradycji cyklicznej Nemezis jest matką Heleny (fr. 7W; Apollod. III 10, 7). Helena, tak jak Pandora, stanowić ma źródło nieszczęść sprowadzonych na ludzkość w postaci kobiety. Wątek ten stanowi więc jedno z wielu etiologicznych objaśnień motywu zagłady herosów widocznego w tradycji cyklicznej i hezjodejskiej ${ }^{11}$. Wojna trojańska $w$ tej perspektywie była realizacją planu boskiego zmierzającego do wyniszczenia pokolenia półbogów, a w rezultacie końca złotego wieku i definitywnego oddzielenia bogów od ludzi. Scholia do Iliady opisują sytuację, w której bóg szyderstwa, Momos, sugeruje Dzeusowi, że sposobem na zmniejszenie populacji ludzkiej, by ulżyć udręczonej Gai, byłoby sprowadzenie na świat zarówno Heleny, jak i Achillesa. Obie te postaci przynoszą śmierć innym, ale i obie jako jedyne w Iliadzie życzą śmierci sobie samym. Wojna zostaje rozpętana przez sprowadzenie przez Helenę i Achillesa eris 'konfliktu, sporu' ${ }^{12}$.

${ }^{11}$ Patrz Finkelberg 2015, która jednak niesłusznie, moim zdaniem, z tego i z innych względów oddziela te tradycje od Homera, którego określa jako meta-epic.

12 Mayer (1996: 13): „Achilles by representing divine succession and by his quarelling with Agamemnon, serves to bring strife - Eris - from the realm of the gods into the earthly political sphere. Helen, created as an embodiment of desire - Eros - serves to bring strife into the realm of the family and marriage". 
Achilles życząc sobie śmierci przeklina eris, która zagnieździła się wśród bogów i ludzi (XVIII 107) ${ }^{13}$. Podobnie przeklina siebie samą Helena i postrzega siebie jako przyczynę wojny.

W szerszej perspektywie makro-opowieści Helena wpisuje się więc w ramę kosmogoniczną, którą wyznaczano przy kreacji poszczególnych fabuł pieśni epickich podejmujących temat wojny trojańskiej (Zieliński 2014: 49, 292-293, 307). Krwawy konflikt pośród ludzi staje się odbiciem i metonimiczną realizacją sporu między bogami.

W poematach homeryckich charakterystyka tej postaci i kwestia jej winy nie są jednak tak jednoznaczne. Wypowiedzi jednych postaci zdają się ją uniewinniać, podczas gdy sama Helena przypisuje sobie winę za wojnę i nieszczęścia, które przyniosła (choć niekiedy także się uniewinnia). Korzystny wydaje się tu krótki przegląd stanowisk badaczy interpretujących te sprzeczności w przedstawieniu roli heroiny w Iliadzie.

G.J. Ryan zaproponował interpretację, odbiegającą od zadomowionych w nauce ustaleń, sugerującą, że wypowiedzi Heleny są nieszczere i nieuczciwe, a postać ta jest $\mathrm{w}$ istocie rozwiązła, egocentryczna, podstępna i uwodzicielska (Ryan 1965). Na reakcję nie trzeba było długo czekać, F.J. Groten podważył zasadność tych sugestii, konkludując, że kwestia odpowiedzialności Heleny nie stoi w centrum fabuły, a Homer celowo pozostawia odbiorcę w niepewności (Groten 1968: 39).

Nowsze badania wprowadziły problem relacji fabuły Iliady do oralnej trady-

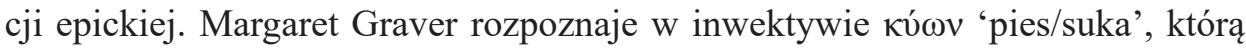
Helena kieruje do samej siebie, znaczenie przypisywane temu określeniu w poezji jambicznej, gdzie obrazowało ono zarzut zachłanności ${ }^{14}$. Nazywając się w ten sposób Helena wskazuje na swoją niosącą zgubę zachłanność, co stanowić ma nawiązanie do wersji tradycyjnej, w której jest ona przyczyną wojny nie tylko dlatego, że jest nagrodą dla tych, co ryzykują za nią życie, lecz dlatego, że aktywnie wpłynęła na bieg wypadków oczarowując Parysa i decydując się na ucieczkę z nim. Helena poczuwa się zatem do winy, widząc swoje powodowane popędem seksualnym działanie w metaforycznym obrazie łakomstwa padlinożernego zwierzęcia (Graver 1995: 54). Homer ze swej strony stara się, zdaniem Graver, uwolnić ją od tego zarzutu, sugerując jej niewinność wyrażaną w słowach włożonych w usta Priama, że to bogowie są odpowiedzialni za nieszczęścia niesione przez wojnę (III 164) (Graver 1995: 59).

Mary Ebbot przyjmuje za Lang, że w Iliadzie tradycyjna historia wojny trojańskiej została przekształcona w historię gniewu Achillesa i w konsekwencji tradycyjny obraz Heleny jako nagrody dla walczących wymagał również zmia-

${ }^{13}$ Przybycie Eris na wesele Peleusa i Tetydy uwolniło ciąg zdarzeń prowadzących do wojny trojańskiej.

${ }^{14}$ Graver (1995: 53): ,the $\kappa \cup ́ \omega v$... labels its object as greedy and potentialy cannibalistic in the domain of material goods, or of fighting sexuality, or speech". 
ny (Ebbot 1999; Lang 1995). Ebbot akceptuje również obserwacje Martina, że wszystkie wypowiedzi Heleny zawierają elementy lamentu rytualnego goos ${ }^{15}$. Obarczanie się winą i życzenie sobie śmierci przez Helenę stanowią echo lamentu pogrzebowego i pozwalają na szczególne wprowadzenie tradycyjnego tematu winy Heleny. W obydwu poematach homeryckich temat jej hańby jest starannie unikany i jedynie sama Helena wypowiada kierowany do samej siebie zarzut odpowiedzialności za wojnę. Pozostałe postaci nie dostrzegają jej winy lub ją od niej uniewinniają. Jedynie Helena kwestionuje więc swoją wartość jako ceny płaconej za wojnę ${ }^{16}$. Tym sposobem stłumiona została możliwość artykułowania negatywnych reakcji na Helenę przez pozostałe postaci, które obarczałyby ją winą za nieszczęścia wojny, ale nie wyeliminowana, gdyż wina Heleny jest rzeczywista ${ }^{17}$. Słowa Heleny pozwalają uzewnętrznić hańbę - nemezis - która „w inny sposób nie jest wypowiadana w Iliadzie"18. Można by jednak powiedzieć, że nie jest to argumentacja spójna. Jeżeli standardowe dla kobiet było obciążanie się winą podczas lamentów pogrzebowych, dla publiczności Homera słowa Heleny nie miałyby większego znaczenia. Trudno zakładać, by miały ewokować u słuchaczy wspomnienie tradycyjnej winy Heleny. To raczej odmawianie jej winy przez inne postaci intrygowałoby publiczność. Całe rozumowanie oparte jest również na jeszcze mniej wiarygodnym pomyśle, że opowieść o gniewie Achillesa miałaby stanowić novum w tradycji epickiej wojny trojańskiej. Był to raczej temat wielokrotnie, w wielu fabułach eksploatowany ${ }^{19}$.

We wnikliwej analizie Hanna Roisman pokazuje z kolei, jak złożony jest obraz Heleny w Iliadzie. Nie powstaje on dzięki przeobrażeniu wskazującym na rozwój postaci, lecz w kolejnych odsłonach ujawniają się inne elementy stanowiące

${ }^{15}$ Wystąpienie Richarda Martina na konferencji w Lozannie (Maj 1995), na które powołuje się Ebbot, rozwijało tezy zawarte już w The Language of Heroes (Martin 1989: 87-88). Murnaghan 1999: 209 twierdzi, że większość wypowiedzi kobiet w Iliadzie jest strukturalnie lub tematycznie powiązana z lamentacją.

${ }^{16} C f$. Collins (1988: 51): ,only Helen can blame Helen without exposing the paradox, that the poem wishes to remain hidden: that the very act which necessitates a war over her also condemns her from the poem's point of view, and renders her as unworthy object of struggle. The Iliad's portrait of a reformed and contrite Helen is certainly formed in answer to this paradox".

${ }^{17} C f$. Austin (1994: 43): „The old men's response to Helen epitomizes her ambiguity. 'It is no disgrace that the Greeks and the Trojans suffer long evils for such a woman,' they say, using the word nemesis, the strongest term in Homer's shame culture for 'blame.' ... But the elders of Troy could not be more mistaken, thinking their war over Helen was free of nemesis: Helen is nemesis."

${ }^{18}$ Ebbot (1999: 20): „The funeral lament, with the mourner's articulation of the perceptions of others, opened the door for this nemesis to enter epic, and the negative view of Helen conventionally belonged to Helen's own lament as an accurate reflection of her status after the death of Hektor. As the focus of the story of the Trojan War shifted to the story of the wrath of Achilles, a critical view of Helen gained importance as an accompanying question about the reasons for the war, and so sentiments proper to the funeral lament became features of all of Helen's speeches".

19 Zieliński 2014: rozdz. I, II i V. 
pogłębienie jej charakterystyki ${ }^{20}$. Helena porusza się w obrębie narzuconych jej ograniczeń i żadnemu z nich nie daje się podporządkować. Nestor (II 356) i Menelaos (II 589-590) widzą w niej ofiarę gwałtu Parysa, litując się nad nią starają się uzyskać akceptację dla swoich racji w tej wojnie. Helena jest traktowana przedmiotowo jak jeden, choć wyjątkowy, ze skarbów zabranych przez Parysa ze Sparty, ale jej status odbiega od statusu innych branek będących ofiarami wojny, jak Chryzejda czy Bryzejda. Nie może jednak swobodnie decydować o swoim losie i odejść do poprzedniego męża, tęsknotę za którym manifestuje. Priam sugeruje, że o jej losie postanowili bogowie, a zatem podporządkowana jest działaniom bogów. Helena jako jedyna z postaci Iliady wyraźnie buntuje się przeciw woli Afrodyty, która jest jej narzucona. Roisman zauważa także, że status branki i przedmiotu posiadania powinien ją właściwie uniewinniać od wszelkich zarzutów, tymczasem napotykamy wyraźne ślady obwiniania jej o wywołanie wojny przez Trojan i przynajmniej niektórych Achajów. Podnosząc lament nad zwłokami Hektora Helena opisuje zmarłego jako jej jedynego poza Priamem obrońcę przed złymi językami pozostałych członków rodziny (XXIV 767). Skoro również starcy trojańscy na widok Heleny zarzekają się, że nie można jej winić za krwawą walkę Trojan i Achajów, zdają się odnosić do rzeczywistych zarzutów formułowanych przez pozostałych Trojan. Zdaniem Roisman, starcy przerzucają wówczas winę na walczące strony (Roisman 2006: 7). Podobnie dzieje się, kiedy po chwili Priam stwierdza, że w jego oczach to nie synowa jest winna, lecz bogowie (III 164).

Helena pierwszy raz ukazuje się, tkając tkaninę obrazującą walkę Achajów i Trojan jako cierpienie dotykające ich z jej powodu, co oznaczałoby, że uznaje ona swoją winę (III 125-128) ${ }^{21}$. Winę tę wyraża expressis verbis $\mathrm{w}$ rozmowie z Priamem na murach Troi (III 173-176). Wiąże się to z manifestowaniem szacunku dla teścia. To zachowanie ma za zadanie zarówno zjednać go dla niej, jak i zachować między nimi dystans. Helena grzecznie odpowiada na niezbyt sensowne, w interpretacji Roisman, pytania starca, który stara się na wszelki sposób nawiązać kontakt z piękną kobietą, ale z czasem stara się przerwać tę męczącą ją rozmowę ${ }^{22}$. Helena stara się później przeciwstawić bogini zmuszającej ją, by udała się do sypialni, gdzie czeka na nią Parys. Bogini stara się ją zwabić odmalowując atrakcyjną seksualność Parysa (III 390-394). Helena, zdaniem Roisman, nie pozwala się zredukować do roli kobiety uległej wobec żądzy seksualnej, hardo wymawiając się bogini. Rysuje przy tym swój obraz kobiety, dla której istotne są przyzwoitość i szacunek ze strony innych kobiet, a w konsekwencji wyrażane są pragnienie odrzucenia izolacji społecznej i tęsknota za

${ }^{20}$ Roisman (2006: 33): „The progression the poem traces is rather the graduated unveiling of her personality in all of its richness".

${ }^{21}$ Rosman (2006: 10): „In taking responsibility, Helen seems to accept society's generally negative view of her conduct. ... unlike Paris, she never denies or mitigates her own responsibility".

${ }^{22}$ Roisman 2006: 11-15; ibid. 2005. 
powrotem do normalnego życia. Pomimo też tego że ulega mężowi idąc z nim do łóżka, prowokacyjnie wyraża swoją dezaprobatę a nawet pogardę dla niego (III 428-436) ${ }^{23}$. W kolejnej scenie, gdy odwiedza ich Hektor, by wezwać brata do powrotu do walki, Helena dystansuje się od męża, który „nie zna wstydu” i szuka wsparcia dla siebie ze strony szwagra ${ }^{24}$. Ostatni raz Helena pojawia się podczas pogrzebu Hektora, przyłączając się do lamentów kobiecych i wykonując swój goos po Andromasze i Hekabe. Roisman ocenia, że jest to pierwsza mowa ,in which Helen not only tells of her isolation but protects against it publicly, even as she continues to reproach herself for her role in the Trojan War and even as she continues to wish for death" (Roisman 2006: 32).

Ruby Blondell z kolei widzi kwestię winy Heleny w perspektywie oddziaływania wykonującego poemat homerycki rapsoda na słuchaczy, licznie zgromadzonych podczas agonów odbywających się na Panathenajach ${ }^{25}$. Pozwala to wnioskować o możliwościach kształtowania obrazu kobiety wobec męskiej publiczności. Nawet bowiem jeżeli kobieta dopuszcza się przewinienia na tle seksualnym, co określane będzie jako działanie pod wpływem Afrodyty lub Erosa, to w żaden sposób nie stanowi to dla niej usprawiedliwienia, a wręcz przeciwnie - jest za swój postępek obwiniana ${ }^{26}$. Helena uwalniana jest od winy przez postaci męskie, lecz sama w opozycji do tych głosów nie stara się usprawiedliwiać, lecz obwinia samą siebie. $Z$ jednej strony, jej samoobwinienie stanowi potwierdzenie jej odpowiedzialności za konsekwencje postanowienia ucieczki z Parysem (którą Blondell ocenia jako jednoznaczny element tradycji), z drugiej „rozbraja” ewentualną męską naganę, która mogłaby ją za to spotkać. W ten sposób samoobwinienie daje portret „a 'good' woman who deeply regrets her single, terrible misdeed” (Blondell 2018: 117). Sens tych zabiegów sprowadza się do potrzeby zyskania akceptacji dla tej postaci u męskiej publiczności: „The rhapsod's putatively male external audience can likewise accept Priam's paternalistic excuse in part because Helen herself does not accept it. ... The remorse that is so central to that voice [Heleny - K.Z.] allows both performer and audience to have their cake and eat it too, accepting Priam's benevolent, paternalistic use of the divine defense as a way to save Helen's lovely face without in the last resort excusing her scandalous behavior" (Blondell 2018: 118).

${ }^{23}$ Roisman (2006: 23): „Her speech to Aphrodite had been sharp, sarcastic, and even insulting, but there was a familiar, good-humored, woman-to-woman quality to it, which stopped short of vituperation. Her address to Paris is a derisive and contempt-filled declaration of aversion and dislike".

${ }^{24}$ Roisman (2006: 27-28) słusznie odrzuca interpretację Ryana, że Helena stara się uwieść Hektora.

${ }^{25}$ Blondell 2010; 2013: rozdz. 3; 2018.

${ }^{26}$ Blondell (2018: 114): „Women are considered innately susceptible to this kind of influence, but that was not, in the larger cultural purview a reason for excusing them, but the opposite: a reason for blaming (and controlling) them". 


\section{Helena wobec zarzutu winy}

Z tej obfitości problemów łączących się z pieczętowaniem i anulowaniem winy Heleny przyjrzyjmy się przede wszystkim kwestii, w jaki sposób formułowana jest wina lub niewinność heroiny przez postaci eposu. Pozwoli to ujrzeć zagadnienie w zupełnie nowym świetle.

Kiedy Helena zabiera głos w początkowej części utworu, jej wypowiedzi, choć zróżnicowane pod względem formy w zależności od tego, do kogo się zwraca, zdają się układać w powiązaną tematycznie sekwencję.

Pierwsza jest odpowiedzią na zaproszenie Priama, by usiadła przy nim i opowiedziała mu o krewnych i przyjaciołach, których oglądają z murów trojańskich. To uprzejme zachowanie króla stanowi jednak reakcję na to, co na jej widok mówią do siebie zgromadzeni wokół niego starcy: co prawda wyrażają zrozumienie dla tego, że młodzi toczą ze sobą o nią długotrwałe zmagania, ale wyrażają życzenie, że lepiej byłoby, gdyby została odesłana skąd przyszła. To stwierdzenie wyraźnie wskazuje na postrzeganie Heleny jako nie tylko drogocennego skarbu, ale i skarbu, który przynosi zgubę, którego nie należy przyjmować, a skoro już został przyjęty, jak najszybciej się go pozbyć (stosownie do koncepcji Burkerta Helena pełni rolę 'pięknego nieszczęścia' przekazywanego wrogowi, by przenieść nieszczęście na wroga ${ }^{27}$ ). Jej piękność jest zwodnicza - przynosi zgubę. Możemy, oczywiście, zakładać, że zdania wypowiadane przez starców odpowiadają stanowisku wielu Trojan, ale wypowiedź Priama, mimo że kierowana do Heleny, stanowi odpowiedź nie na hipotetyczne opinie innych Trojan, obwiniających $\mathrm{He}-$ lenę, lecz na bezpośrednie uwagi swojego otoczenia ${ }^{28}$. Tylko pozornie bowiem

27 Porównanie opisów pewnych rytuałów hetyckich, gdzie nieczystość przekazywana jest wrogowi na jego zgubę pod postacią przyozdobionego barana lub kobiety, z greckimi zapisami mitograficznymi pozwoliło Burkertowi (Burkert 1979) na rekonstrukcję wspólnego schematu rytualnego, w którego manifestacjach mitycznych dokonują się przetworzenia, skutkujące między innymi przekształceniem w narracji konia-włóczni dourios hippos w Drewnianego Konia wypełnionego wojownikami, przekazanego Trojanom na ich zgubę. Podobnie Helena porwana przez Parysa przynosi klęski Trojanom, którzy ją przyjęli. Słabością tego odczytania roli Heleny jest pewna niekompatybilność obrazu epickiego ze wzorem rytualnym: ani nie zostaje przekazana celowo, ani Trojanie nie zostają oszukani przez Achajów. Burkert stara się wzmocnić swoją hipotezę obserwacją, że Helena nie może wrócić do domu, co w epice obrazuje jej tułaczka z Menelaosem w drodze powrotnej, jakkolwiek to również nie harmonizuje z obrazem przedstawionym w Odysei, gdzie Helena przebywa po powrocie w domu z mężem.

${ }^{28}$ Blondell (2018: 116) ocenia sytuację jako intymną rozmowę, ale mimo to uznaje, że Priam stara się zachować twarz wobec innych kierując się dobrem swojej rodziny: „As king of Troy, Priam also has an interest in excusing Helen in order to justify continuing the war for ten long years. As long as the Greeks and Trojans are willing to keep fighting over Helen they cannot afford to admit that she is guilty, since this would impair her value by making her damaged goods. This problem is especially acute for the Trojans, whose retension of Helen is on its face inexplicable. But this particular excuse also serves a further purpose for Priam. Everyone else agrees on the guilt of his son Paris, whose seduction of Helen is directly instigated by Aphrodite. Priam's vague reference to the 
uniewinniają one Helenę stwierdzeniem, że „nie ma nemesis, dla walki o nią”. W rzeczywistości rozpoznają w Helenie przyozdobioną kobietę, która ściąga zgubę na tych, którzy się na nią połakomią. Słowa starców nie mają siły sprawczej mythos, określane są jako skrzydlate ${ }^{29}$, ale wprowadzają zagrożenie, które może stać się realne w innych okolicznościach. Priam stwierdza, że to nie Helena, lecz bogowie są winni wprowadzeniu wojny w granice jego kraju (III 164-165). To zrzucanie winy na bogów jest konwencjonalnym sposobem na ratowanie jakiejś osoby przed pogardą i agresją innych ${ }^{30}$.

Helena, zanim udzieli odpowiedzi w sprawie tożsamości postaci, o którą pyta Priam, wraca do tematu swojej winy. Wbrew stanowisku Priama, które odsuwało od niej podejrzenia, sama podnosi tę kwestię (III 173-176):

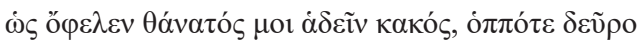

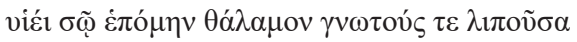

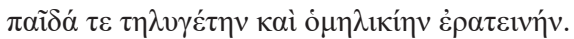

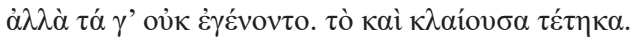

'gods' displaces divine causation away from this specific goddess, and toward larger divine plan, making it easier to excuse not just Helen but Paris, together with himself and the Trojans collectively". Interpretacja tych usprawiedliwień jako potrzeby zachowania twarzy (prezentowana również przez Scodel 2008) wydaje mi się nie odpowiadać należycie mechanizmom rywalizacji słownej w kulturze oralnej, opartych na przekonaniu o winie moralnej, gdzie prestiż jednostki nieodłącznie wiąże się z zagrożeniem jej wykluczenia ze społeczności.

${ }^{29}$ Martin (1989: $12 \mathrm{nn}$.) podkreśla aspekt autorytatywny i performatywny mythos, który to rodzaj wypowiedzi jest ściśle powiązany z działaniem, które jest konsekwencją słów; zakłada się, że rzeczywistość ma przyjąć kształt określony w wypowiedzi, stąd określam to jako mowę sprawczą. Potrzeba zapewnienia sprawczości słów wynika z konieczności utrzymania przez jednostkę swojej pozycji w grupie, zwłaszcza w przypadku jej liderów, którzy swoją stanowczość chcą łączyć $\mathrm{z}$ dążeniem do zyskania akceptacji grupy dla swojego zdania. W przeciwieństwie do tego 'słowa skrzydlate' nie mają siły sprawczej, w ocenie Martina są to akty mowy (speech-acts) pełniące funkcję różnie formułowanej dyrektywy (Martin 1989: 30-35). Można zatem wnioskować, że słowa starców trojańskich nie determinują losu Heleny, lecz stanowią sugestię co do tego, jak należałoby z nią postąpić.

30 Analogiczny zabieg stosuje Nauzykaa, która będąc pod wrażeniem zwracającego się do niej z błaganiem rozbitka, ratuje go przed zarzutem, że sam jest winien swoich nieszczęść. By zabezpieczyć Odysa przed pogardą otoczenia, Nauzykaa wypowiada prawdę obiegową, że bogowie są zmienni w swych łaskach i w chwili obecnej zesłali mu nieszczęście, tak jak wcześniej zsyłali powodzenie (Od. VI 186-190). Że jest to zwyczajowy szablon używany w takich sytuacjach, dowodzi podobna wypowiedź Achillesa o bogach rozdających dobro i zło, która ma ochronić przed pogardą Priama przedstawiającego mu ogrom swoich nieszczęść (Il. XXIV 525-533). Na realność działania zarzutu, że nieszczęście stanowi wynik utraty łaski bogów, powodującego odrzucenie prośby i okazanie pogardy, wskazuje potraktowanie Odysa przez Eola przy drugiej wizycie u niego (Od. X 72-75, vide Zieliński 2021: 71-72).

Blondell (2018: 117) zauważa jedynie, że takiego przerzucenia winy na bogów w celu obrony przed zarzutem dokonuje raczej ktoś inny niż osoba obwiniana, zwłaszcza ktoś, kto ma interes w obronie obwinianego (podaje przykład piastunek Dejaniry i Fedry, które troszczą się o swoje panie, Trach. 441-448, Hipp. 451-458). W jej opinii jednak chodzi o zachowanie twarzy. 
Oby śmierć podła mi się spodobała ${ }^{31}$ wtedy, gdy tu

Podążyłam za twoim synem do komnaty małżeńskiej opuszczając krewnych,

I dziecko wychowywane ze specjalną troską, i ulubione rówieśniczki ${ }^{32}$.

Ale tak się nie stało i nad tym płaczę.

Przyznaje się do zrobienia czegoś niewłaściwego, czego jednak nie można cofnąc ${ }^{33}$. Gdyby wówczas umarła, kiedy zdecydowała się podążyć za Parysem, nie dotknęłyby jej nieszczęścia. Swojego czynu nie postrzega więc w kategoriach przyczyny wojny, lecz osobistej straty domu i rodziny. Ton ten utrzymuje mówiąc potem o szwagrze Agamemnonie i nazywając samą siebie kynōpis 'o wyglądzie psa/suki'. Sprowadziła zatem nieczystość, lecz na swoich rodaków. Najciężej jej hańbę muszą znosić bracia, którzy, jak sądzi, ze wstydu nie chcą pokazać się nawet na polu walki ${ }^{34}$. Podobnie zatem jak w przypadku Parysa, który uznaje zasadność postawienia mu zarzutów przez Hektora (III 59-66), przyznanie się do winy ma za zadanie uwolnić ją od odpowiedzialności. O ile jednak Parys używa przy tym środków typowych do prowadzenia sporu ${ }^{35}$, o tyle riposta Heleny jest kamuflowana. Przyznaje się do sprowadzenia nieszczęścia, lecz na innych - nie tych co stawiają jej zarzut. Haniebność jej postępku dotyka Achajów, Trojanie pozostają wolni od zmazy. Nie można więc stawiać jej tego zarzutu, nie dlatego że

${ }^{31}$ Sugestia, że lepiej było popełnić samobójstwo. Elmer (2013: 40-44) wskazuje, że czasownik handanō 'podobać się' w dyskursie homeryckim sugeruje zachowania egotyczne, nie liczące się z opinią i reakcją grupy. Helena sugerowałaby zatem być może, że jej zachowanie, polegające na podążeniu za Parysem i zyskaniu statusu jego żony, nie było egoistyczne.

${ }^{32}$ O niewłaściwości jej zachowania wskazuje jedynie wzmianka o dziecku. Pozostałe elementy sugerują, jakby opuszczała dom jako panna młoda udająca się do domu męża. Helena zdaje się ważyć słowa i nie wspominać Menelaosa ani jego prawa do niej, bo mogłoby narażać ją to na niezadowolenie teścia. Jej wina jest przez to dyplomatycznie zawoalowana.

33 Jest to zatem odczuwanie atē, stosownie do interpretacji Wyatta, mimo że termin ten nie pada w tym miejscu. Deklarowanie atē jest jednak, jak zaznaczyliśmy, zachowaniem pożądanym społecznie.

${ }^{34}$ Austin (1994: 48) przyjmuje, że Helena okazuje wstyd szczerze: „Helen assumes the worst: her brothers, kinsmen and dauntless warriors though they are, did not dare show themselves on the battlefield for shame (Il. 3.326-342). Her assumption is incorrect, but that is less important than Helen's reminder that the spectacle ... is the spectacle of her own shame, or lack of it".

${ }^{35}$ Parys potwierdza zasadność zarzutów kierowanych wobec niego przez brata, mimo że ten domaga się dla niego roli kozła ofiarnego, którego należy wyeliminować przez ukamienowanie. Parys deklaruje, że nie widzi żadnej przesady w zarzutach brata i odnosi się tylko do tego, co wywołało naganę Hektora, czyli do jego zachowania na polu walki i krytyki jego atrakcyjności seksualnej. Wykorzystuje więc zasadę stosowaną w sporze: podważenia ostatniego zarzutu (Zieliński 2019b), by pominąć dużo ważniejszy zarzut, odnoszący się do nieszczęścia, które ściąga na całe miasto. Parys potrafi się zatem uchylić przed kompromitującym oskarżeniem stosując przy tym zaskakujący i ryzykowny fortel uznania zasadności zarzutów. Nie oznacza to przyznania się do winy - skrucha jest pozorowana - dodane bowiem zastrzeżenie pełni funkcję kontrataku dyskredytującego napastnika. Parys stosuje porównanie, w którym krytykuje brata za niewyważone słowa, a następnie, mimo że nagana Hektora jest tak stanowcza i jednoznaczna, znajduje furtkę dla naprawienia sytuacji i odzyskania honoru. Decyzja o podjęciu walki z Menelaosem anuluje bowiem całkowicie zarzut tchórzostwa i nie pozwala na kontynuowanie sporu. 
jest nieprawdziwy, jak sugerował Priam, lecz ponieważ jest nietrafiony. Priam nie mógł zupełnie uwolnić ją od winy - „dla niego" nie jest winna, dla innych wciąż taka może pozostawać ${ }^{36}$. Sama Helena broni się dużo skuteczniej.

Helena znajduje dość szczególny sposób, by zaznaczyć swoją podmiotowość. Przeklinając samą siebie odwołuje się do mechanizmu magicznej fetyszyzacji, której poddana była również Bryzejda, branka, z której Achilles i Agamemnon czynią przedmiot sporu, stanowiący substytut prawdziwych przyczyn ich poróżnienia ${ }^{37}$. W następnych słowach Helena wskazuje jednak na własną decyzję zostawienia męża, krewnych i dziecka. Obnaża więc sposób, w jaki jest uprzedmiotowiana, znajdując $\mathrm{w}$ wyznaniu swej winy miejsce na dumne podkreślenie autonomiczności swej decyzji. Nie zrzuca bowiem, jak broniący się przed zarzutami Agamemnon, winy na bogów (XIX 87-91).

W spór, którego w tej sytuacji udało jej się uniknąć, heroina wchodzi niedługo potem z Afrodytą. Nie dając się zwieść przybraniu przez boginię wyglądu jej służącej i słowom nakłaniającym ją do udania się do Parysa, zwraca się do niej z ostrym atakiem (III 399-412).

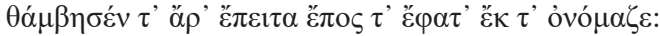

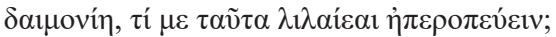

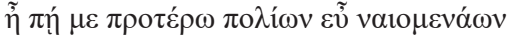

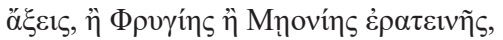

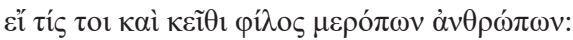

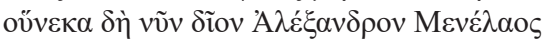

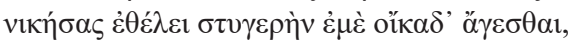

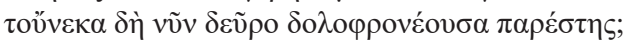

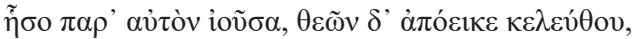

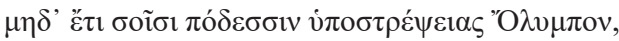

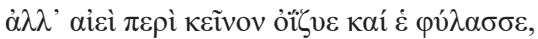

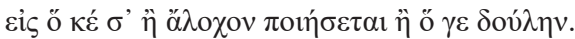

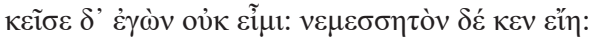

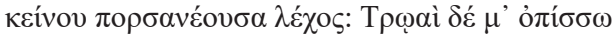

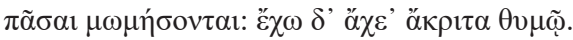 \\ Zdumiała się i taką mowę wypowiedziała: \\ „okrutna, dlaczego pragniesz zwodzić mnie tymi słowami? \\ Dokąd-że dalej poprowadzisz mnie, do którego z ludnych miast? \\ Czy do Frygii, czy uroczej Meonii?
}

${ }^{36}$ Priam akcentuje dwukrotnie $\mu$ oı „dla mnie”: bogowie są 'jemu' winni i 'jemu' sprowadzili wojnę (III 164-165). Cf. Teffeteller 2003: 18.

${ }^{37}$ Achilles obciąża winą Bryzejdę za to, że była przyczyną sporu i lepiej żeby dosięgła ją śmierć w chwili, kiedy została wzięta do niewoli (XIX 58-62). Proces magicznej fetyszyzacji sporu stanowi przejaw przerzucania winy na substytut. Kobieta, która była jedynie przedmiotem sporu, staje się w jego wyniku winną konfliktu, tak jak narzędzie „zbrodni” uznane zostaje winnym w ateńskim rytuale bufonii. Wina zostaje na nią przeniesiona jak w hetyckim rytuale zażegnywania sporu na owcę lub szczeniaka (KBo 39.8 II 26-34, KBo 39.8 aw. II 35-43, cf. Nowicki 2013: 214-215) oraz w hebrajskim rytuale na kozła dla Azazela (Lev. XVI 7-26). 
Jeśli ktoś ci tam jest miły spośród ludzi obdarzonych mową,

Ponieważ teraz Menelaos, pokonawszy boskiego Aleksandra,

Zamierza poprowadzić mnie znienawidzoną do domu,

Czy to dlatego pojawiasz się knując [kolejny] podstęp?

Idź i usiądź sobie obok niego, zejdź z drogi bogów,

Rezygnując całkiem z powrotu na Olimp [dosł. nie wracając już na Olimp swoimi stopami],

Ale na stałe płacz nad nim i strzeż go,

Za co on uczyni cię żoną lub niewolnicą!

Ja tam nie pójdę. Ściągnęłoby to na mnie gniew społeczności [nemesis],

Gdybym poszła $\mathrm{z}$ nim do łóżka ${ }^{38}$. Trojanki by ze mnie potem

Wszystkie szydziły. Nieprzerwane jest pasmo cierpień w moim sercu.

Helena zarzuca bogini posługiwanie się oszustwem, w czym pozostawałaby nienasycona. Sugeruje bowiem, że na popychaniu jej w ramiona Parysa nie poprzestanie. Stosowana regularnie w sporach dyskredytacja przeciwnika jest kontynuowana w bezpośrednim 'przerzuceniu zadania': 'jeśli jest tak atrakcyjny, sama mu ulegaj'. Na koniec ujawnia, że dobrze zdaje sobie sprawę, że kobiety trojańskie obwiniają ją za nieszczęścia zesłane im a nie Achajom. Można by powiedzieć, że mężczyzn oszukać jest łatwiej ${ }^{39}$ - wobec kobiet sugestia, że przyniosła hańbę i nieszczęście swoim rodakom, nie miałaby raczej szansy powodzenia.

Odpowiedź rozgniewanej bogini napawa heroinę przerażeniem. Wysłuchawszy jej, Helena ruszyła bez słowa za Afrodytą. Bogini zagroziła jej bowiem, że sprowadzi na obie walczące strony takie klęski, że Helena zginie 'złą śmiercią' kakon oiton (III 416-417). Afrodyta wydaje się więc świadoma triku, który Helena zastosowała wobec starców trojańskich. W chwili, kiedy obie strony zdadzą sobie sprawę, że doznają nieszczęść $\mathrm{z}$ winy Heleny, nie ma dla niej ratunku ${ }^{40}$ - nie będzie mogła prowadzić rozgrywki, w której pozostaje nagrodą dla wygranej strony ${ }^{41}$. Zła śmierć oznaczać musi rozpoznanie tej kobiety jako źródła nieszczęść przez obie strony, a więc niezależnie od tego, kto zwyciężyłby, Helena zginie

${ }^{38}$ Kirk (1985: 324): „Presumably their reason [słów nagany ze strony Trojanek] would be indecent haste, rather than accepting her (second) husband again at some point after his apparent defeat in the duel". Wyjaśnienie Kirka zdaje się jednak wypaczać intencje Heleny, która ma pretensje do bogini, że w ogóle doprowadziła do sytuacji, w której się teraz znajduje. Gotowość do nagany kobiet trojańskich (teraz już wszystkich, wcześniej być może część z nich nie obwiniała Heleny) wynika z narażania ich na utratę mężów i synów, do czego impulsem stawałby się jej powrót do Parysa, który nie rozstrzygnął konfliktu trwale na ich korzyść.

39 Także Blondell (2010: 11) dostrzega w samoobwinieniu Heleny sposób na manipulowanie mężczyznami.

${ }^{40} \mathrm{Na}$ potencjalność postawienia jej takiego zarzutu przez Achajów wskazuje nazwanie jej  troklosa Achillesa (XIX 325).

${ }^{41} \mathrm{Na}$ takie rozgrywanie stron wskazuje Odyseja. W opowieści Menelaosa Helena wyraźnie sprzyja Trojanom (Od. IV 266-289), natomiast w opowieści Heleny miała ona sprzyjać Achajom (IV 244-264), wspierając Odyseusza i namawiając się z nim w sprawie, jak się można domyślać, zdobycia Troi. 
haniebną śmiercią kozła ofiarnego ${ }^{42}$, kumulując w sobie całą nieczystość wyobrażoną w nieszczęściach wojny ${ }^{43}$.

Samo jednak wystąpienie z zarzutami wobec bogini stanowi odwrócenie mechanizmu obrony, w którym winę przerzuca się na bóstwo. W ten sposób przedstawiona jest niezwykła odwaga i samoświadomość Heleny: z jednej strony, niczym heros, przeciwstawia się bóstwu i zarzuca mu egoistyczne pobudki, narażając się na jego gniew, z drugiej, wyraźnie nie chce oszukiwać samej siebie, zakładając swoją niewinność. Helena nie zrzuca odpowiedzialności na boginię, lecz czyni jej zarzut z negatywnych konsekwencji boskiego działania.

Kiedy w komnacie małżeńskiej zostaje posadzona naprzeciw Parysa, zwraca się do niego w mowie określonej jako sprawcza (mythos), przyjmującej charakter nagany (III 428-436). Wypowiedź jest zaprawiona szyderstwem: Helena przypomina mu przechwałki, że pokona Menelaosa, każe mu więc iść z powrotem i je zrealizować. Dodaje jednak, że wyprawa nie ma sensu, bo Menelaos i tak go pokona. W żaden więc sposób nie jest to zapowiedź czegoś, co ma się spełnić, gdyż zawiera sprzeczność: Parys ma iść, ale lepiej niech nie idzie ${ }^{44}$. Parys nie zamierza jednak odpowiedzieć na zaczepkę. Tłumaczy zwycięstwo Menelaosa chwilowym wsparciem ze strony Ateny i wyraża przekonanie, że pokona go przy innej okazji ze wsparciem bogów, którzy jego wspierają. Istotniejsze dla niego jest jednak w tej chwili uprawianie miłości z Heleną - wyraźnie więc bagatelizuje problem, ale może sobie na to $\mathrm{w}$ rozmowie z Heleną pozwolić ${ }^{45}$.

${ }^{42} C f$. Blondell (2010: 23-24), która sądzi, że chodzi o pozbawienie Heleny przez boginię urody i możliwości budzenia pożądania seksualnego pozwalającego jej uwodzić mężczyzn i wygrywać ich na swoją korzyść.

${ }^{43}$ Ostatnio pojawia się wiele zastrzeżeń wobec koncepcji Douglas (2007), ale teza o irracjonalności zmazy jest niepodważalna.

${ }^{44}$ Dlatego uważam, że jest to chybione, niewłaściwe mythos. Oznaczałoby to, że kobiety nie tyle nie mogą, co nie potrafią formułować takiej mowy. Martin (1989: 88, przyp. 73), dostrzega niewłaściwe użycie mythos w rywalizacji słownej (flyting words), lecz wyjaśnia to nieco inaczej: „At 3.427, she also begins the dialogue, but her speech is explicitly flyting toward Paris (énipape muthoi i), whose response is framed in similar terms (437). Again, the audience must judge Helen to have a knowledge of genre, but she is seen to misuse the flyting conventions in a significant way, switching from abuse to a lament theme in mid-course (See 433-436 on her fears that Paris will be killed if he confronts Menelaos). Of course, the other possibility is that she is being sarcastic here, and so resembles more conventional warriors in her abuse".

${ }^{45}$ Lekceważenie zarzutów Heleny przez Parysa można jednak również widzieć jako zwycięską odpowiedź w konfrontacji słownej. Najpierw unieważnia zarzut, że jest przegranym, sugerując, że jest tylko chwilowym przegranym, a potem wygrywa rozgrywkę sprowadzając rywalkę do rangi obiektu aktu seksualnego. Collins (2004: 55-58) pokazuje, że w sporach słownych zarzuty co do rzeczywistych lub wyimaginowanych aktów seksualnych, w których przeciwnik miał brać udział, zwłaszcza w roli pasywnej, są typowe. Argument wspominający, że rywal pełnił w akcie seksualnym rolę bierną w stosunku do wypowiadającego zarzut adwersarza może być argumentem, na który nie ma obrony. Parys wspomina, że posiadł Helenę już wcześniej, a zmuszając ją do stosunku seksualnego teraz potwierdza swoją przewagę. Ten sam mechanizm pojawia się w konfrontacji Odyseusza z Kirke (Od. X 314-335): najpierw heros okazuje się odporny na czary czarodziejki 
Sarkazm, z którym zwróciła się do Parysa Helena, wynika z faktu, że jako mąż nie potrafi zapewnić jej obrony; obrony przed separującą ją od społeczności naganą. Zwycięstwo $\mathrm{w}$ pojedynku z Menelaosem zapewniałoby jej szacunek, którego jej brakuje. Mąż, który nie potrafi ochronić żony przed złymi językami, jest godny pogardy. Helena akceptowałaby więc Parysa, gdyby siłą pozbył się jej poprzedniego męża.

Helena sygnalizuje, że bardziej niż rozstrzygnięcia na polu bitwy, które decydować będą o jej przyszłym losie, interesuje ją zwykłe życie w mieście, gdzie żyje niemal w izolacji od innych kobiet, które mają do niej złe nastawienie ${ }^{46}$. Pokazuje to ważny aspekt życia społecznego, kobiety tworzą niezależnie od ich przynależności do swoich oikoi 'domostw' grupę, w której toczy się nieustanna rywalizacja kształtująca hierarchię, w dużym stopniu niezależnie od posiadanego statusu ${ }^{47}$. Najmniej pożądaną rzeczą i najbardziej niebezpieczną w skutkach jest separacja jednostki. Helena jest przekonana, że jej status zależy od zachowania jej męża, jej umiejętności prowadzenia sporu nie wystarczają zatem w gronie kobiet, gdzie narażona jest na poniżające szyderstwa, a może raczej potrzebuje dla prowadzenia tych rozgrywek oparcia w odpowiednim zachowaniu męża.

(anulowanie skuteczności jej mocy), a następnie grozi jej mieczem, na co Kirke reaguje gotowością do podporządkowania się oferując odbycie stosunku seksualnego. W obu przypadkach zaznaczona jest nierówność płciowa: kobieta przegrywa (jej środki są nieskuteczne) i dobrowolnie poddaje się seksualnie mężczyźnie.

${ }^{46}$ Zupełnie zatem przeciwnie do tego, co jest przedmiotem obaw Andromachy, która martwi się o to, co stanie się po śmierci jej męża i po klęsce Trojan (VI 407-413). Andromacha nie musi się jednak martwić o opinię innych kobiet, gdyż działania Hektora w pełni ją chronią przed atakami $\mathrm{z}$ ich strony. Znamienne jest, że Andromacha wspomina o poniżeniu czekającym ich syna po śmierci Hektora w społeczności Trojan (XXII 485-501). Sytuacja ta, która wydaje się wielu badaczom wręcz niewiarygodna, skoro chodzi o syna księcia i wodza Trojan, stanowi jednak odzwierciedlenie przekonania, że pozycja dzieci, tak jak żony, wyrażająca się w akceptacji ich przez społeczność, zależy od aktywności męża. Jeszcze raz podkreślić wypada, że prestiż nie jest wartością statyczną, lecz dynamiczną.

47 Early (1993: 142 nn.) przedstawia, jak w rozmowach, także kłótniach prowadzonych przez kobiety baladi w Kairze przekazywane są oczekiwania kulturowe co do zasad dystrybucji szacunku i ustalania hierarchii w kontekście odpowiedniego zachowania. Edwards 1979 (za: Collins 2004: 231-232) przedstawia z kolei starcia słowne kobiet klasy pracującej w Gujanie, zwane busin, które mają miejsce, gdy któraś z nich nie okaże publicznie należnego szacunku drugiej. Eye-pass dispute jest wynikiem niezauważenia jakiejś osoby, co odebrane jest przez 'niezauważoną' kobietę jako działanie umyślne. 'Pominięcie wzrokiem' drugiej osoby stanowi naruszenie hierarchicznej równowagi społecznej. Kobiety wypominają sobie przewinienia prawdziwe i takie, o których krążą plotki (w małych społecznościach znają się i muszą wiele wiedzieć o sobie), przy czym w miarę toczącego się sporu wyciągane są coraz cięższe zarzuty, włącznie z oskarżeniami lub pomówieniami o pozamałżeńskie kontakty seksualne. Zwycięstwo odnosi ta z kobiet, która sukcesywnie wyjawiając niemoralne prowadzenie się rywalki znajdzie akceptację w oczach publiczności innych kobiet, które pełnią rolę sędziów. Ich wyrok oznacza opowiedzenie się za jedną ze stron. Przegrywa kobieta, która wpada w większe zakłopotanie i nie znajduje odpowiedniej odpowiedzi na zarzuty. 
Taki właśnie stosunek Heleny do męża stoi za ponowieniem nagany wobec męża wyartykułowanej przy okazji odwiedzenia ich przez Hektora (VI 343-358):

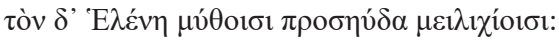

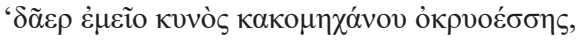

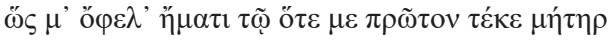

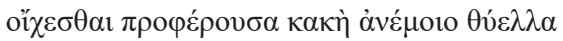

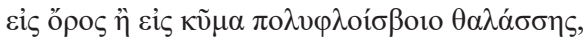

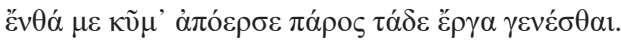

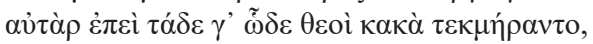

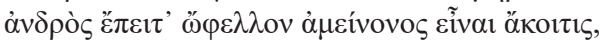

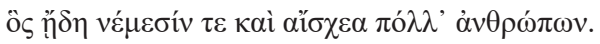

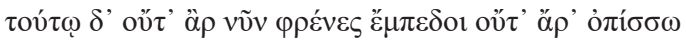

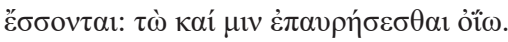

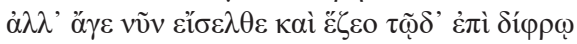

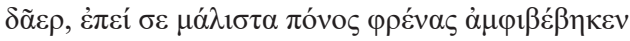

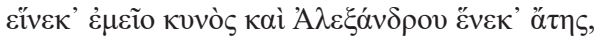

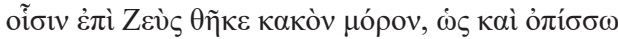

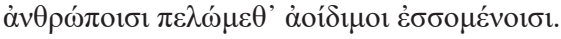

Do niego Helena odezwała się uprzejmymi słowami:

„Szwagrze mój suki sprowadzającej okropne nieszczęście [wyrządzającej krzywdę]

Oby w dniu stanowiącym początek [proton], gdy urodziła mnie matka,

Uniósł mnie zły burzowy poryw wiatru

W góry lub w fale uderzającego o brzeg morza,

Tam porwała mnie fala, zanim to wszystko się stało.

Jednak skoro te nieszczęścia bogowie w ten sposób zaplanowali,

Obym mogła należeć do lepszego męża,

Który wiedziałby, co to gniew naprawiający krzywdę [nemesis] i liczne hańbiące czyny

[aischea] ludzi.

A ten tu nie potrafi odpowiednio załatwić sprawy ani teraz, ani w przyszłości nie będzie:

Ale sądzę, że obu tych rzeczy [nemesis i aischea] doświadczy.

Wejdź teraz i usiądź na tym krześle,

Szwagrze, ponieważ to na ciebie spada staranie o wszystko,

$\mathrm{Z}$ powodu mnie suki i z powodu błędu [atē $]$ Aleksandra.

Dzeus nałożył nam taki podły los, abyśmy także w przyszłości

pośród ludzi, którzy przyjdą, byli opiewani w pieśniach.

Warto zwrócić uwagę, że to, co mówi Helena, stoi w sprzeczności do tonu, który przyjmuje. Ukazywanie swojej hańby nie może być emocjonalnym odruchem, w którym ujawnia się wstyd, jeżeli wypowiadane jest to w słowach pełnych miodowej słodyczy. Roisman zauważa, że Helena nie stara się w Hektorze znaleźć sprzymierzeńca, który obroniłby ją przed złymi językami, tak jak nie potrafi tego zrobić jego brat $^{48}$. Badaczka zauważa również, że w poprzedzającej

${ }^{48}$ Rzeczywiście, Hektor niewiele jej może pomóc w jej relacjach z kobietami. Wydaje mi się, że Helenie chodzi raczej o to, by Hektor wpłynął na jej męża (Hektor zwraca się do Parysa z naganą za 
jej wypowiedź mowie Parys kłamliwie sugeruje bratu, że żona namawia go również do powrotu do walki (jest to również cel wizyty Hektora) malakois epeessin 'łagodnymi słowami'. Nic bowiem nie wskazuje, aby tak było naprawdę: oboje w milczeniu zajmują się swoimi sprawami, kiedy przychodzi Hektor, a w poprzedniej wypowiedzi Heleny, która chciała jej nadać ton stanowczego mythos ${ }^{49}$, ostro z niego szydziła. Wskazana sprzeczność tonu i treści sugeruje, że Helena wcale nie jest bardziej szczera od męża.

Ponownie, tak jak wobec Priama, zaczyna mowę od niezrealizowanej klątwy. $\mathrm{W}$ porównaniu $\mathrm{z}$ tamtym wystąpieniem pojawia się jednak w słowach Heleny istotna różnica: sugeruje, że lepiej by jej było tragicznie umrzeć tuż po narodzinach, a nie wtedy, gdy uciekła z Parysem. To, co zrobiła z Parysem - tade erga 'te oto czyny', było skutkiem tego, co się stało, w dniu jej urodzin. To tam umieszcza Helena prōton ‘początek' zdarzeń. Przeniesienie przyczyny nieszczęść do dnia jej urodzin wydaje się wiązać $\mathrm{z}$ tradycyjnym motywem Heleny jako nieszczęściem mającym zakończyć czas herosów. W kontekście jej wypowiedzi motyw ten zostaje wykorzystany, by wyolbrzymić jej winę. Samobiczowanie jest bowiem jeszcze bardziej spektakularne: pokazuje się jako osoba od początku przeklęta. Wszystko, co się stało, jest zatem jej winą, bo jest „nieczysta” i same żywioły natury powinny były ją unicestwić. Obraz jej śmierci jest też analogiczny do losu 'kozła ofiarnego' zrzucanego w górską lub morską przepaść. Jeżeli w rozmowie z Priamem posłużyła się samopotępieniem jako sposobem na uciszenie głosów nagany, to w rozmowie z Hektorem nie musiała się tego obawiać. Mimo to nie tylko powtarza ten zabieg a jeszcze stosuje go w formie wyolbrzymionej. Jedynym powodem, dla którego warto byłoby to robić, jest pokazanie się jako kobiety skrajnie nieszczęśliwej. Helena sugeruje, że wie, że jest przyczyną nieszczęść innych, ale sama również jest pokrzywdzona, nie przez kogoś, lecz przez los, za którym stoi zrządzenie najwyższego boga ${ }^{50}$. Hektor, gdyby próbował znajdować w niej winę, nie mógłby jej zarzucić, że dopuściła się występku z jego bratem ${ }^{51}$, lecz musiałby potwierdzić, że jest przeklęta, co jest możliwe, ale niezbyt odpowiada mentalnemu obrazowi Hektora w Iliadzie.

Do tych słów Helena dodaje frazę, która zdaje się dopełniać tradycyjny motyw Heleny-zguby ludzkości, że tade kaka 'te właśnie [które przeżywamy] nieszczęścia’ zrządzili bogowie. Jej narodziny miały być przecież częścią planu

to, że siedzi w domu uchylając się od walki, gdyż wstrzymuje go gniew III 326), by jego zachowanie przysporzyło jej chwały niezbędnej do poprawy jej sytuacji w społeczności.

${ }^{49}$ Ta wypowiedź jest również określona jako mythoi (1.mn. od mythos), Helena stara się więc wpłynąć na Hektora swoimi słowami, ale jest równie nieskuteczna, gdyż Hektor odmawia jej zaproszeniu.

${ }^{50}$ Helena ma prawo zakładać, że Hektor mógł słyszeć nieprzychylne dla niej opinie od bliskich mu kobiet (matki, żony, sióstr).

${ }^{51} \mathrm{Na}$ potencjalność postawienia Helenie takiego zarzutu przez Hektora wskazuje nazwanie jej przez niego w emocjonalnej naganie wobec swego brata mega pēma 'wielkim nieszczęściem' (III 50-51), analogicznie do tego jak nazywają ją starcy na murach Troi ( $p \bar{e} m a$, III 159-160). 
Dzeusa (Dios boulē). Jednak w tym kontekście słowa te nabierają innego znaczenia - sugerują niewinność Heleny. Bohaterka przerzuca więc winę na bogów, podobnie jak zrobił to wcześniej Priam. Przemyślnie Helena łączy wypowiedź swoją i Priama w jeden zmodyfikowany argument, który miałby jej zapewnić przychylność szwagra ${ }^{52}$. Hektor nie odpowiada jednak na zapewnienia Parysa, że do niego dołączy, i wymawia się od gościny oferowanej przez Helenę. Pośród wielu interpretacji tego zachowania warto zwrócić uwagę, że Hektor zdaje się dystansować od obojga małżonków. Być może chodzi o to, że nie daje się zwieść ani nieszczerości Parysa, ani Heleny.

Wszystkie te wypowiedzi wiążą Helenę z ‘początkiem’ zdarzeń, tymczasem jej ostatnie wystąpienie stanowi manifestację ich 'końca' nie tylko ze względu na to, że zamyka właściwie akcję Iliady. W sposób typowy dla lamentów żałobnych Helena wychwala poległego Hektora jako swojego jedynego obrońcę i skarży się na swój los (Alexiou 2002: 21-22; Seaford 1994: 86-92). Zdaniem Roisman, Helena wyraża protest przeciwko szykanom, które spotykały ją w Troi. Istotna jest jednak reakcja na jej goos - cały lud przyłącza się do opłakiwania (XXIV 776). Poszczególne lamenty nad zwłokami Hektora wywołują reakcję otoczenia, która jest każdorazowo inaczej ujmowana (XXIV 745, 760, 776). Po każdym wystąpieniu krąg ludzi przyłączających się do lamentu poszerza się - następuje stopniowa infekcja gwałtownego uczucia rozpaczy i żalu (rodzaj histerii zbiorowej): od grupy kobiet pełniących funkcję płaczek po wystąpieniu Andromachy, przez wszystkich domowników po lamentach Hekabe, do całego ludu po wystąpieniu Heleny (Zieliński 2019a: 6). Helena znajduje akceptację dla swoich słów u wszystkich Trojan. Znajduje u nich zrozumienie dla swojego cierpienia. Działa to jednak także w drugą stronę: gdy kończy się w ten sposób okres jej izolacji, staje się ona częścią społeczności skazanej na klęskę, której wyrazem jest śmierć Hektora. Helena staje się w ten sposób ofiarą nieszczęścia, którego stała się przyczyną. Spotykały ją krzywdy ze strony tych, których krzywdziła, ale teraz pospołu cierpią to samo nieszczęście ${ }^{53}$. O ile więc wcześniej publicznie dystansowała się od sprawy trojańskiej wyrażając tęsknotę za powrotem do rodziny i kraju, o tyle teraz staje się częścią tej rodziny i kraju, w którym przebywa ${ }^{54}$.

${ }^{52}$ W wypowiedzi Heleny obserwujemy sprzeczność: albo sama jest przyczyną nieszczęść, albo winni są bogowie. Nie chodzi jednak o nieumiejętność posługiwania się logiką, lecz o wykorzystywanie perswazyjne różnych ujęć tego samego problemu, w celu uniemożliwienia postawienia jej zarzutu. W logice postrzegania nieszczęścia jako niezamierzonego błędu, zobrazowanej przez Evans-Pritcharda i Douglas, obydwie przyczynowości mogą występować obok siebie nie wykluczając się wzajemnie i nie świadczy to ani o stosowaniu „kobiecej” logiki, ani nielogicznego myślenia ludzi pierwotnych, co sugerowała koncepcja Levy-Bruhla.

53 Jest to zatem sytuacja analogiczna do zrównania się w cierpieniu doświadczającym wszystkich ludzi Achillesa i Priama, którzy mimo że są wrogami jedzą wspólny posiłek jak philoi (Kim 2000: 63-64, 149-151; Zieliński 2021: 81-84).

${ }^{54} C f$. Pantelia 2002, który dostrzega w poemacie przesłanie o charakterze uniwersalnym i transcendentnym, którego elementem jest mowa Heleny mająca za zadanie ugruntować sławę opłakiwanego bohatera w pieśni. 
Roisman uważa, że Helena przechodzi drogę od milczenia, kiedy snuje swoją opowieść o wojnie tkając tkaninę, do wypowiedzi publicznej wobec zgromadzonej całej społeczności Trojan. Można by powiedzieć, że komentarz narratora do opisu przedstawienia wojny na tkaninie oznaczałby, co właściwie szczerze myśli Helena o sobie i o swojej roli w wydarzeniach. Natomiast wszystkie jej wypowiedzi są uwarunkowane relacjami z poszczególnymi rozmówcami i stanowią jej formę walki o przeżycie. Helena wykazuje się na pewno dużą inteligencją potrafiąc zaryzykować samopotępienie służące jej obronie - w rzeczywistości zależy jej na dobrej opinii ludzi, pośród których żyje, a zwłaszcza kobiet, które od niej stronią, obwiniając ją o swoje cierpienia i swój lęk przed przyszłością. Będąc piękną kobietą imponuje mężczyznom i stosunkowo łatwo sobie z nimi radzi, czego nie można powiedzieć o jej stosunkach z kobietami ${ }^{55}$. Jako kobieta nie potrafi jednak wypowiedzieć mowy sprawczej (mythos), próbując zastosować ją wobec Parysa, gubi się w sprzecznościach, ostatecznie pozostając mu uległa. Zignorowana również została przez Hektora.

${ }^{55}$ Blondell (2010: 117) uważa, że wyrozumiałość męskich postaci względem Heleny wynika z postrzegania jej jako przedmiotu rozgrywki mężczyzn. Tymczasem kobiety trojańskie traktują ją podmiotowo, tzn. przekonane są o jej winie, gdyż umiała wykorzystać swoje wdzięki do uwiedzenia Parysa, czego konsekwencją jest wojna. „Women, familiar with the constraints under which women labor as 'objects' in men's eyes, are willing to blame other women for the actions they take within the limits of such constraints”. Urok Heleny („,both erotic and heterosexual”) działa na mężczyzn, ale nie na kobiety. Kobiety nie mają udziału w męskiej ideologii zdobywania sławy kleos, dlatego: ,in this context the reported hostility of other women towards Helen is scarcely surprising. It suggests that they, unlike the men, are unable to perceive a single woman - even this one - as an transcendent object that justifies the war as a glorious struggle".

Należy jednak poczynić istotne rozróżnienie: dla Trojanek Helena nie jest przyczyną wojny, lecz doświadczanego i grożącego nieszczęścia: wojna nie jest sprawą kobiet, lecz doświadczenie straty bliskich lub upokorzenia w sytuacji, gdy przypada im rola branek, już jest. W środowiskach kobiecych status kobiety wiąże się z realizacją wyobrażeń o „dobrej” kobiecie, które mogą być oparte na patriarchalnym modelu społecznym, ale często znacznie poza ten model wykraczają (kogo można nazwać 'prawdziwą' lub 'dobrą' żoną, matką, córką itp.). Zwraca się uwagę, że Helena nie obnosi się ze swoją urodą i pozycją, ani w ubiorze, ani w zachowaniu, grając rolę dobrej, skromnej, zwykłej żony. W sytuacji zbiorowego nieszczęścia, wszystko to może jednak okazać się niewystarczające. Fakt, że Helena pojawia się w Troi w niekonwencjonalny sposób, w sytuacji, gdy narasta kryzys, naraża ją na stosunkowo łatwe wiązanie ją z nieszczęściem i separowanie się od niej środowiska, dla której pozostaje osobą obcą. Takie zachowanie społeczne pojawia się niezależnie od czasu i miejsca. Jako przykład można podać historię przedstawicielek świata zachodniego, które jako żony władców starały się o uznanie społeczności, do których trafiły: Hope Cooke, Amerykanki, która została żoną króla Sikkim (obecnie Indie), a podobnie można ocenić sytuację Farah Pahlavi, żony Rezy Pahlaviego, która mimo że była Iranką, została zapoznana przez szacha w Paryżu i czyniła starania o europeizację kulturową Iranu, zwłaszcza jeśli chodzi o poprawę sytuacji społeczno-polityczną kobiet. Admiracja dla tych kobiet ze strony miejscowych zmieniła się radykalnie w pogardę i nienawiść, gdy pojawiło się powszechnie odczuwane nieszczęście. To one stały się w powszechnym odczuciu winne niekorzystnej sytuacji, w której się znaleźli. Z drogocennego skarbu, któremu przypisuje się magiczne działanie zapewnienia powszechnego szczęścia, stały się w opinii powszechnej źródłem zła, którego należy się pozbyć. 
Helena jest w sytuacji między młotem a kowadłem, co uświadamia jej Afrodyta: obie strony mogą przelać na nią swój żal i gniew. W każdej chwili może stać się ofiarą. Identyfikowana jest przez starców jako kobieta-zguba, której należy się pozbyć. Sama również opisuje swoją możliwą śmierć jako przynależną kozłowi ofiarnemu. Mówiąc o niej wytrąca jednak swoim oskarżycielom broń z ręki. To niezwykle finezyjna strategia. Obarcza się winą, może nawet w jakimś stopniu ją odczuwa pozostając długi czas w izolacji, ale na wszelkie sposoby broni się, aby inni nie mogli jej zarzucić winy. To oznaczałoby dla niej wyrok śmierci. Achajowie, Nestor i Menelaos, nie widzą w niej winy, lecz wspominają jedynie cierpienia, których doświadczać musi Helena w niewoli trojańskiej ${ }^{56}$. Ich wypowiedzi trudno jednak uznać za szczere - obie są obliczone na zyskanie akceptacji armii dla swoich celów $^{57}$. Nestor, by pobudzić ducha bojowego Achajów, łączy współczucie dla losu Heleny z żądzą zemsty i zysku, gdy każdy ze zwycięzców będzie mógł wziąć sobie kobietę trojańską (II 355-356). Podjęcie wątku współczucia wskazuje, że równie ważne jak podsycenie żądz żołnierskich, istotne jest dostarczenie im motywacji ideologicznej - walcząc muszą być przekonani, że racja jest po ich stronie, a posiadanie racji wiąże się z przyjęciem statusu osoby skrzywdzonej.

\section{Atrybucja winy w Iliadzie}

Kwestia winy prezentowana jest z zastosowaniem typowej dla stylu oralnego Homera rekonfiguracji elementów: ta sama rzecz może przybierać w związku z tym różne wartości. Nigdy wina nie jest wskazywana wprost przez narratora w bezwzględnie sformułowany sposób. Kwestia ta pojawia się w dyskursie: poszczególne postaci atakują innych zarzucając im winę lub też zapewniają o ich niewinności, atakowani starają się z kolei winę z siebie zrzucić, ale też czasami się do niej przyznają, choć nie dlatego, że gotowi są ponieść za nią karę. Prezentowana jest więc cała gama wariantów przyznania się do winy.

${ }^{56}$ W Zdobyciu Ilionu (stosownie do streszczenia Proklosa) Menelaos zamierza zabić żonę, ale ona ratuje się pokazując mu obnażone piersi. Posługiwanie się gestem (tu obliczonym na uwypuklenie swojej atrakcyjności seksualnej) wydaje się prostszym sposobem na osiągnięcie powodzenia niż wyrafinowane konstrukty słowne, na których koncentruje się Homer. Bez wątpienia jednak gest ten ukazuje ten sam problem ambiwalentności pozycji Heleny w całej tradycji. Z jednej strony, jest ona przedmiotem pożądania, z drugiej, przedmiotem nienawiści obu stron. W Iliadzie Menelaos nie wspomina słowem o Helenie, nawet wtedy gdy decyduje się na pojedynek o nią z Aleksandrem. Jedynie w Katalogu Okrętów narrator zaznacza, że Menelaosem kierowała żądza zemsty za troski własne i cierpienia Heleny (II 589-590; Kirk (1985: 214) wskazuje, że fraza ta jest gramatycznie niejasna i może oznaczać również krzywdy wyrządzane z powodu Heleny). Nie artykułuje więc swego gniewu na nią, mimo że ona sama wspomina o ucieczce od męża (III 174).

57 Blondell (2012: 5) słusznie zauważa, że: „Making Paris, not Helen, the target of blame makes the Achaean quest for revenge ( $\tau \dot{\sigma} \sigma ı \varsigma$ ) - for men's retribution against men - central to the complex of excuses for the war." 
Kwestia winy jest aplikowana w Iliadzie do wielu postaci: Agamemnona, Parysa i wszystkich Trojan, Heleny, jak również Achillesa i pełniących funkcję jego substytutu Patroklosa i Thersytesa ${ }^{58}$. Spójrzmy, jak na tle niektórych z tych postaci wchodzących w podobny dyskurs przedstawia się zachowanie Heleny relatywizujące jej odpowiedzialność za nieszczęścia doświadczane przez innych.

Agamemnon nie zamierza przyjąć odpowiedzialności za swoje postępowanie doprowadzające do zarazy dziesiątkującej szeregi achajskie. Uniemożliwia postawienie mu zarzutu, odwracając sytuację: przedstawia się jako ten, który społeczność z kryzysu wyprowadza, a nie ten, który ją do niej doprowadził (I 106-120). Kiedy ta strategia została podważona przez Achillesa (I 121-129), stara się przerzucić winę na adwersarza (I 176-177). W żaden sposób nie zamierza przyznać się do winy, narażając armię achajską na kolejne klęski.

Atryda przyznaje się później do winy wobec starszyzny, ale jednocześnie usprawiedliwia się, że zostało na niego zesłane zaślepienie atē, co oznacza, że żałuje tego, co zrobił, ale i sprawia to, że nie można stawiać mu zarzutów (IX 115121). Jeszcze silniej eksponuje to wobec wszystkich Achajów, gdzie swój błąd zrównuje z błędem popełnionym przez Dzeusa XIX 86-144). Przyznanie się do winy nie skutkuje pociągnięciem go do odpowiedzialności - argument popadnięcia w zaślepienie (żalu za to, co się zrobiło) służy bowiem jako forma uniewinnienia.

Parys przyznaje się do winy wobec całej armii trojańskiej, gdy zarzucił mu ją ostro Hektor, ale ratuje się przed gniewem społeczności decydując się na działanie pozwalające mu wykazać swoją niewinność przez eliminację zagrożenia, czyli usuwając z ich ziemi Achajów po zabiciu Menelaosa (III 59-75).

Helena przyznaje się do winy w sposób jeszcze bardziej wyrafinowany, wymusza bowiem na tych, do których kieruje swoje słowa, powstrzymanie się od stawiania jej zarzutów. Potrafi sprawić, że Priam widzi winę nie w niej, lecz w działaniu bogów. Publicznie wychwala też zachowanie teścia oraz szwagra, Hektora, że jako jedyni nie czynili jej wyrzutów. W przeciwieństwie do prób uniewinnienia Heleny nikt nigdy nie oczyszcza Parysa z winy.

Wariantywne jest również przerzucenie winy na kogoś innego. Agamemnon przerzuca winę na Achillesa, zmieniając istotę sporu: w miejsce zarzutu sprowadzenia zarazy na Achajów stosuje zarzut sprowokowania sporu. Siła tego argumentu jest również eksponowana przez Menelaosa wskazującego na Parysa jako tego, który zapoczątkował spór (III 100). Argument 'winny jest ten, kto zaczął' wykazuje dużą skuteczność. Zdaje sobie z niego sprawę Helena, która w samoobwinianiu wskazuje swoje działanie jako 'początek' nieszczęść. Udaje się jej jednak zredu-

${ }^{58}$ Wina Achillesa, która spada na niego jako przegranego w sporze z Agamemnonem, nawet jeżeli z naszego współczesnego punktu widzenia niezasadna (wina nie jest jednak uznawana obiektywnie), zostaje uznana (społeczność achajska nie staje po jego stronie, a więc w rezultacie staje po stronie Agamemnona) i prowadzi do separacji herosa (choć dobrowolnej), a w konsekwencji musi prowadzić do poniżającego ukarania i eliminacji. Tę rolę w narracji Iliady spełniają odpowiednio jego substytuty: Thersytes i Patroklos. 
kować jego siłę wobec Priama i starców widząc swą winę w kontekście hańby dla Achajów, a w mowie do Hektora dokonując przerzucenia winy na bogów.

Diomedes w sytuacji pierwszego sporu z Agamemnonem przyjmuje zarzut skierowany do niego przez Atrydę, nawet jeżeli jego przyjaciel, Sthenelos, podważał jego zasadność (IV 404-418). Przy innej okazji jednak, kiedy Agamemnon wskazuje na winę Dzeusa (IX 23-25), Diomedes przerzuca winę na Agamemnona, zyskując akceptację dla swojego zdania kontynuowania walki bez Atrydy (IX 37-48). Agamemnon, odseparowany od całej armii, znajduje się w tym momencie w śmiertelnym niebezpieczeństwie, z którego wybawia go Nestor. Helena nie przerzuca winy na kogoś innego (jedynie w jednym momencie na bogów), gdyż umiejętnie potrafi uniknąć postawienia jej publicznie zarzutu.

\section{Konkluzje}

Wypowiedzi Heleny i innych postaci odnoszących się do zagadnienia jej winy mają każdorazowo charakter perswazyjny. Obciążenia jej winą jest niezwykle niebezpieczne, dlatego Priam podejmuje próbę zdezawuowania zarzutu, kiedy tylko pojawia się w wypowiedziach starców z jego otoczenia. Helena lepiej jednak radzi sobie z tym sama, używając w śmiały i przemyślny sposób strategii obciążania winą samej siebie; tylko po to jednak, by osoby jej nieprzychylne nie mogły wystąpić wobec niej z tym zarzutem otwarcie. Nie można jednak powiedzieć, że wszystko jej się udaje: próby narzucenia swojej woli młodym mężczyznom - Parysowi i Hektorowi kończą się fiaskiem: zostaje zlekceważona a nawet zmuszona przez męża do uległości seksualnej ${ }^{59}$. Jej mythoi nie mają siły sprawczej i prawdopodobnie wynika to z przekonania, że ten rodzaj wypowiedzi zarezerwowany jest dla mężczyzn ${ }^{60}$. Helena wyraźnie stara się zaznaczyć swoją samodzielność, stojącą w kontraście do przeznaczonej jej w tradycji roli przedmiotu rywalizacji mężczyzn. Kiedy jednak próbuje męskiego sposobu bycia, odnosi niepowodzenie, choć próbuje zarówno używania słów twardych wobec męża i przymilnych wobec szwagra. Pozostając w shame culture Helena koncentruje swoje wysiłki na zapewnieniu sobie dobrej opinii, która to potrzeba w jej przypadku ukazuje całą swoją powagę, ponieważ zła opinia w obliczu doznawanych przez zbiorowość cierpień może skutkować wylaniem na nią agresji całej społeczności, agresji

59 Sugestie Blondell (2010: 22-27), że Heleną powoduje w tym momencie pożądanie pobudzone w niej przez Afrodytę, są bezpodstawne.

${ }^{60}$ Martin (1989: 87): „Given the male, heroic in-group orientation of the word muthos, and its association with powerful self-presentation, it would seem to be a social taboo for women to employ this kind of speech. But it turns out that Helen and Hekabe, both of whom address Priam with a muthos at other points in the poem, are actually enacting laments in the speeches labeled with this word. That is to say, they fulfill an expected performance role, using a recognized genre of muthos as memory - but they are presented as doing so at unexpected times, to create dramatic effect". 
będącej wynikiem kumulowanych przez długi czas bólu i lęku. Dopiero kiedy na pogrzebie Hektora Helena manifestuje swoje cierpienie uzasadnione stratą opłakiwanego przez resztę społeczności trojańskiej wojownika, po raz pierwszy zrównuje się w nieszczęściu z grupą, pośród której przebywa. Akceptacja społeczności dla jej słów oznacza identyfikację Heleny z Trojanami, w ten sposób zaznaczone zostaje, że przestaje być im obca.

Poszczególni bohaterowie stawiani są więc w pozycji winnych przedstawianych zdarzeń w perspektywie mikro- (epizod Iliady) i makro-opowieści (wojna trojańska). Oznacza to jednak tylko tyle, że opowiadana historia przedstawiana jest w kontekście kulturowym zakładającym winę moralną nieszczęść. Ten właśnie kontekst nadaje znaczenie działaniom bohaterów. W głębokiej tradycji, kiedy tworzyła się ta historia, wybór Parysa rozstrzygającego spór bogiń nie musiał mieć konotacji negatywnych. Dokonywać mógł wyboru trzeciej domeny w trójpodziale Dumézila (Littleton 1970: 233-234). Helena mogła więc pełnić rolę talizmanu zapewniającego pomyślność, dobrobyt i płodność, stąd wszyscy pragną ją mieć i nikt nie chce z niej zrezygnować6 ${ }^{61}$. Helena stanowić mogła ucieleśnienie idei magicznej mocy kumulowanej w innych mitach przez artefakty, takie jak młyn sampo w tradycji karelo-fińskiej lub święty Graal w tradycji chrześcijańskiej $^{62}$. Ciąg reinterpretacji tej historii wnosił jej przewartościowania. Elementy mitu mają charakter binarny, ambiwalentny, więc dobrodziejstwa przynoszone

${ }^{61}$ Rynearson 2013 podejmuje problem podkreślania w Iliadzie, że Helena warta jest życia wielu wojowników, zarówno achajskich, jak i trojańskich. Uważa, że w homeryckim systemie wartości wszystko podlega wymianie i rekompensacie: ludzie, zwierzęta, przedmioty. Helena jednak, podobnie jak Achilles, wyrażają epicki ideał wartości najwyższej, która nie podlega wymianie albo wymieniana być może za życie wielu. Tę ideologię podważa jedynie sama Helena, która żałuje swojego niegdysiejszego kroku i wyraża przekonanie, że wymiana tego, co miała (III 173-176), na to, co ma, była głupia. Kwestionując zasadność wymiany wielu (mąż, dziecko, przyjaciółki) za jednego (Parys) Helena kwestionuje, zdaniem Rynearsona (s. 9), sensowność wymiany wielu istnień ludzkich za jedną kobietę.

Metoda intertekstualna Rynearsona pozwala jedynie oddzielić świat epiki, gdzie sugeruje się istnienie wartości superlatywnej, od racjonalistycznych ujęć nieadekwatności tej wymiany prezentowanych w historiografii i, po części, w tragedii attyckiej. Nie pozwala jednak na rozpoznanie bazy mentalnej takiego uwarunkowania wartości superlatywnej, sugerując jedynie istnienie nierealnego świata poetyckiego. Tymczasem ta wartość Heleny i Achillesa przejawia się w fundamentalnej dla tej kultury ideologii poświęcenia jednostki jako równowartości życia zbiorowości, znanej nam jako kompleks rytualno-mityczny kozła ofiarnego. Zawiera ona również ideę substytucji rządzącą rytuałem ofiarniczym. Tak jak Achilles pełni funkcję herosa, którego zadaniem jest poświęcenie swego życia dla przetrwania całej społeczności (brak Achillesa oznacza śmierć wielu, jego poświęcenie oznacza ratunek dla reszty Achajów a zagładę dla Trojan), tak Helena pełni analogiczną funkcję heroiny, która ambiwalentnie generuje nieszczęścia dla obu stron. W Iliadzie postać Achillesa podlega substytucji (Patroklos, Diomedes, Thersytes), choć nie uwalnia go to od śmierci, jak to się dzieje w rytuale, gdzie poświęcany jest substytut. Helena pozostaje niezastępowalna nawet w micie; tak jak kozioł ofiarny stanowi wartość wymienną za całą społeczność - przynosi śmierć i jednym, i drugim, ale w ostatecznym rozrachunku albo jednym, albo drugim.

${ }^{62} C f$. racjonalizujące wyjaśnienia stawiania przez Achajów i Trojan Heleny jako ceny wartej toczenia o nią wojny dostarczane przez Blondell (2010: 6-8). 
przez kobietę-artefakt mogą generować nieszczęścia wynikające z faktu, że staje się ona obiektem pożądania i zawiści innych. Racja moralna może zostać przeniesiona na stronę, której kobieta-artefakt została odebrana, gdyż racja jest w opowieściach kultury oralnej zawsze po stronie pokrzywdzonej. Opowieść musi być zawsze podporządkowana pewnym determinantom poznawczym. Historię trojańską poznajemy z perspektywy kultury, która wyjaśnia mityczne wydarzenia z perspektywy sporu typującego winnych. Rola Heleny jako 'pięknego nieszczęścia' i Drewnianego Konia jako 'konia-włóczni', rozpoznana przez Burkerta, nie musiała więc stać u źródeł formowania się opowieści, lecz z pewnością interpretacja wytworzona u progu epoki archaicznej każe ją w tych kategoriach postrzegać.

\section{Bibliografia}

Alexiou, M. (2002). The Ritual Lament in Greek Tradition. 2nd ed. revised by D. Yatromanolakis, P. Roilos. Lanham-Boulder-New York-Oxford: Rowman \& Littlefield Publishers.

Austin, N. (1994). Helen of Troy and her Shameless Phantom. Ithaca (NY): Cornell University Press. Blondell, R. (2010). „'Bitch that I am': Self-Blame and Self-Assertion in the Iliad”. Transactions of the American Philological Association 140. 1-32. https://doi.org/10.1353/apa.0.0048

Blondell, R. (2013). Helen of Troy: Beauty, Myth, Devastation. Oxford: Oxford University Press. https://doi.org/10.1093/acprof:oso/9780199731602.001.0001

Blondell, R. (2018). „Helen and the Divine Defense: Homer, Gorgias, Euripides”. Classical Philology 113. 113-133. https://doi.org/10.1086/696821

Burkert, W. (1979). Structure and History in Greek Mythology and Ritual. Berkeley: University of California Press.

Cairns, D.L. (1993). Aidōs: The Psychology and Ethics of Honour and Shame in Ancient Greek Literature. Oxford: Clarendon Press.

Cairns, D.L. (2011). Shame. W: Finkelberg, M. (red.). The Homer Encyclopedia. Chichester: Wiley-Blackwell Publishing Ltd. 790-792. https://doi.org/10.1002/9781444350302.wbhe1329

Collins, D. (2004). Master of the Game: Competition and Performance in Greek Poetry. Center for Hellenic Studies Series. Washington D.C.: Trustees for Harvard University.

Collins, L. (1988). Studies in Characterization in the ,Iliad”. Beiträge zur klassischen Philologie 189. Frankfurt: Athenäum.

Compton, Todd M. (2006). Victim of the Muses. Poet as a Scapegoat, Warrior, and Hero in Greco-Roman and Indo-European Myth and History. Center for Hellenic Studies Series. Washington D.C.: Trustees for Harvard University.

Dodds, E.R. (1951). The Greeks and the Irrational. Berkeley: University of California Press. https:// doi.org/10.1525/9780520931275

Douglas, M. (2007). Czystość i zmaza. Przeł. M. Bucholc. Warszawa.

Dover, K.J. (1975). The Clouds of Aristophanes. Edited with introduction and commentary. Oxford: Clarendon Press.

Early, E. (1993). Baladi Women of Cairo: Playing with an Egg and a Stone. American University of Cairo Press.

Ebbot, M. (1999). The Wrath of Helen: Self-Blame and Nemesis in the Iliad. W: Carlisle, M., Levaniouk, O. (red.). Nine Essays on Homer. Lanham (Md.): Rowman \& Littlefield. 3-33.

Edwards, W. (1979). „Speech Acts in Guyana: Communicating Ritual and Personal Insults”. Journal of Black Studies 10(1). 20-39. https://doi.org/10.1177/002193477901000102 
Elmer, D.F. (2013). The Poetics of Consent: Collective Decision Making and the „Iliad”. Baltimore: The Johns Hopkins University Press.

Evans-Pritchard, E. (1956). Nuer Religion. Oxford: Oxford University Press.

Evans-Protchard, E. (1976). Witchcraft, Oracles and Magic among the Azande. Oxford: Clarendon Press.

Finkelberg, M. (2015). Meta-Cyclic epic and Homeric poetry. W: Fantuzzi, M., Tsagalis, Ch. (red.). The Greek Epic Cycle and its Ancient Reception. A Companion. Cambridge: Cambridge University Press. 126-138. https://doi.org/10.1017/CBO9780511998409.008

Foley, J.M. (1991). Immanent Art: From Structure to Meaning in Traditional Oral Epic. Bloomington, Ind.

Goody, J. (2012). Mit, rytuat i oralność. Przeł. Olga Kaczmarek. Warszawa: Wydawnictwo Uniwersytetu Warszawskiego. https://doi.org/10.31338/uw.9788323521938

Graver, M. 1995. „Dog-Helen and Homeric Insult”. Classical Antiquity 14. 41-61. https://doi. org $/ 10.2307 / 25000142$

Green, M.A. (2002). Dying for the Gods. Human Sacrifice in Iron Age \& Roman Europe. Charleston: Tempus Publishing Ld.

Griffin, J. (2004). The Speeches. W: Fowler, R. (red.). The Cambridge Companion to Homer. Cambridge: Cambridge University Press. 156-167. https://doi.org/10.1017/CCOL0521813026.010

Groten, F.J.Jr. (1968). „Homer's Helen”. Greece \& Rome 15. 33-39. https://doi.org/10.1017/ S001738350001682X

Hooker, J.T. (1987). „Homeric Society: A Shame Culture?”. Greece \& Rome 34. 121-125. https:// doi.org/10.1017/S0017383500028060

Kim, J. (2000). The Pity of Achilles: Oral Style and the Unity of the Iliad. Lanham-Boulder-New York-Oxford: Rowman and Littlefield.

Kirk, G.S. (1985). The „Iliad”: A Commentary, vol. I: books 1-4. Cambridge: Cambridge University Press. https://doi.org/10.1017/CBO9780511620263

Lang, M.L. (1995). War Story into Wrath Story. W: Carter, J.B., Morris, S.P. (red.). The Ages of Homer. A Tribute to Emily Townsend Vermeule. Austin (Tx.): University of Texas Press. 149-162.

Littleton, C. Scott. (1970). Some Possible Indo-European Themes in the ,Iliad”. W: Puhvel, J. (red.) Myth and Law among the Indo-Europeans. Berkeley: University of California Press. 229-246.

Lloyd-Jones, H. (1990). Honour and Shame in Ancient Greek Culture. W: Greek Comedy, Hellenistic Literature, Greek Religion, and Miscellanea: the Academic Papers of Sir Hugh Lloyd Jones. Oxford: Oxford University Press. 253-280.

Martin, R.P. (1989). The Language of Heroes. Speech and Performance in the „Iliad”. Ithaca (NY): Cornell University Press.

Mayer, K. (1996). „Helen and the DIOS BOULH”. American Journal of Philology 117. 1-15. https:// doi.org/10.1353/ajp.1996.0016

Muellner, L.C. (1996). The Anger of Achilles: Mēnis in Early Greek Epic. Ithaca (NY): Cornell University Press.

Murnaghan, S. (1999). The Poetics of Loss in Greek Epic. W: Beissinger, M., Tylus, J., Wofford, S. (red.). Epic Traditions in the Contemporary World. Berkeley: University of California Press. 203-220.

Nagy, G. (1996). Homeric Questions. Austin (Tx.): University of Texas Press.

Nagy, G. (2010). Homer the Preclassic. Berkeley: University of California Press.

Nowicki, S. (2013). Rytuaty oczyszczenia na starożytnym Bliskim Wschodzie: studium mezopotamskich, anatolijskich i ugaryckich technik magicznych. Kraków: Zakład Wydawniczy NOMOS.

Ong, W.J. (2011). Oralność i piśmienność. Stowo poddane technologii. Przeł. J. Japola. Warszawa: Wydawnictwo Uniwersytetu Warszawskiego.

Pantelia, M.C. (2002). „Helen and the Last Song for Hector”. Transactions of the American Philological Association 132. 21-27. https://doi.org/10.1353/apa.2002.0012

Parry, M. (1987). Studies in the Technique of Oral Verse-Making. W: Parry, A. (red.). The Making of Homeric Verse. The Collected Papers of Milman Parry. New York-Oxford: Oxford University Press. 
Roisman, H. (2005). Old Men and Chirping Cicadas in the „, Teichoskopia”. W: Rabel, R.J. (red.). Approaches to Homer: Ancient and Modern. Swansea: Classical Press of Wales. 105-118. https:// doi.org/10.2307/j.ctv1n357ng.9

Roisman, H. (2006). „Helen in the Iliad; Causa Belli and Victim of War: From Silent Weaver to Public Speaker". American Journal of Philology 127. 1-36. https://doi.org/10.1353/ajp.2006.0018

Ryan, G.J. (1965). „Helen in Homer”. Classical Journal 61. 115-117.

Rynearson, N.C. (2013). „Helen, Achilles, and the Psuchê: Superlative Beauty and Value in the Iliad". Intertexts 17. 3-21. https://doi.org/10.1353/itx.2013.0001

Scodel, R. (2008). Epic Facework: Self-Presentation and Social Interaction in Homer. Swansea: The Classical Press of Wales. https://doi.org/10.2307/j.ctvvnbkt

Seaford, R. (1994). Reciprocity and Ritual. Homer and Tragedy in the Developing City-State. Oxford: Clarendon Press.

Teffeteller, A. (2003). „Homeric Excuses”. Classical Quarterly 53. 15-31. https://doi.org/10.1093/ $\mathrm{cq} / 53.1 .15$

Wyatt, W.F. (1982). „Homeric ’ATH”. The American Journal of Philology 103. 247-276. https://doi. org $/ 10.2307 / 294471$

Zieliński, K. (2014). „Iliada” i jej tradycja epicka: Studium z zakresu greckiej tradycji oralnej. Wrocław: Wydawnictwo Uniwersytetu Wrocławskiego

Zieliński, K. (2019a). „Women as Victims of War in Homer's Oral Poetics”. Humanities 8. 1-16. https://doi.org/10.3390/h8030141

Zieliński, K. (2019b). „Selecting a Scapegoat. The problem of guilt and group domination in the dispute between Achilles and Agamemnon". Anodos - Studies of the Ancient World 14. 245-252.

Zieliński, K. (2021). The Flexibility of Traditional Norms in the Perspective of Changes in Oral Narratives. The Case of Homer. W: Czeremski, M., Zieliński, K. (red.). Worldview in Narrative and Non-narrative Expression: the Cognitive, Anthropological and Literary Perspective. Wiesbaden: Harrassowitz Verlag, 59-87.

Dr hab. Karol Zieliński prof. UWr. - (b. 1968) dr hab., classical philologist, hellenist. Professor at the Institute of Classical, Mediterranean and Oriental Studies (University of Wrocław). Head of the Centre for Interdisciplinary Research on Relations between Oral and Written Culture. Chief editor of "Quaestiones Oralitatis". Specialises in Greek literature of the archaic period, especially with a view to its links with oral tradition. Monographs: Stonce w rozpaczy. Liryka milosna Safony w aspekcie oralności [The Sun in Despair. Sappho's love lyric poetry in the aspect of orality], Wrocław 2006, Iliada i jej tradycja epicka. Studium z zakresu greckiej tradycji oralnej, Wrocław 2014. A revised version of the latter, in English translation, is scheduled for publication in 2021 as The Iliad and its Oral Epic Tradition (Center for Hellenic Studies Series, Trustees for Harvard UP).

e-mail: karol.zielinski@uwr.edu.pl 